Mycologia, 107(6), 2015, pp. 1285-1303. DOI: 10.3852/15-097

(c) 2015 by The Mycological Society of America, Lawrence, KS 66044-8897

\title{
The genus Hebeloma in the alpine belt of the Carpathians including two new species
}

Ursula Eberhardt ${ }^{1}$

Staatliches Museum für Naturkunde Stuttgart, Rosenstein 1, D-70191 Stuttgart, Germany.

Ghent University, Department of Biology, K.L. Ledeganckstraat 35, B-9000 Ghent, Belgium

Anna Ronikier

Institute of Botany, Polish Academy of Sciences, Lubicz 46, PL-31-512 Krakow, Poland

Nicole Schütz

Staatliches Museum für Naturkunde Stuttgart, Rosenstein 1, D-70191 Stuttgart, Germany

Henry J. Beker

Rue Père de Deken 19, B-1040 Bruxelles, Belgium. Royal Holloway College, University of London, Egham, United Kingdom

Abstract: Between 2002 and 2012 regular visits to the Carpathians were made and a number of Hebeloma spp. were collected from the alpine area. In total 44 collections were made that represent 11 species, two of which, Hebeloma grandisporum and $H$. oreophilum, are described here as new. Of the 11 species, four (H. alpinum, H. marginatulum and the two species described as new) are known only from alpine or Arctic habitats. Hebeloma dunense and $H$. mesophaeum are commonly found in, but not restricted to, alpine habitats. The other five species (H. aanenii, H. laterinum, H. naviculosporum, H. vaccinum, $H$. velutipes) are usually found in lowland or boreal habitats. Hebeloma naviculosporum is reported for the first time from the alpine zone and $H$. alpinum for the first time as growing with Helianthemum. All but two species (H. alpinum, H. marginatulum) are reported for the first time from the Carpathian alpine zone. In this paper we discuss the habitat, the 11 recorded species and give detailed descriptions of the two new species, both morphologically and molecularly. A key for Hebeloma species from sect. Hebeloma occurring in Arctic-alpine habitats is provided.

Key words: Agaricales, basidiomycetes, ectomycorrhizal host, RPB2, TEF1a

\section{INTRODUCTION}

High-mountain areas and Arctic regions, with alpine grasslands and tundra formations developed under

Submitted 15 Apr 2015; accepted for publication 10 Aug 2015.

${ }^{1}$ Corresponding author. E-mail: ursula.eberhardt@smns-bw.de severe climatic conditions, belong to the most interesting natural model systems for ecological and biogeographical studies (Körner 2003). They harbor specific groups of plants, animals and fungi that evolved from adaptation to these harsh environmental conditions and further diversified through vicariance, ecological niche shifts and other processes. In circumpolar regions Arctic tundra extends over large, continuous areas, whereas in the mountains of lower latitudes the alpine zone is fragmented. The Carpathians are one of the main European mountain chains. Although the $209000 \mathrm{~km}^{2}$ total surface and about $1300 \mathrm{~km}$ length make them comparable in size to the Alps (Kondracki 1978), they are characterized by a considerably different physiography. They are much lower in altitude than the Alps and the alpine belt extends over a much smaller area $\left(1000 \mathrm{~km}^{2}\right.$, which is $3.5 \%$ of the total surface; Ozenda 1985) and is highly fragmented (Pawłowski 1970) (Fig. 1).

Macrofungi are important elements of Arctic-alpine ecosystems; they are, for example, mycorrhizal symbionts of several key plant species of such areas, such as Betula nana, Dryas octopetala, Kobresia spp. and dwarf Salix spp. (Gardes and Dahlberg 1996). A systematic survey of Arctic-alpine fungal species in all important areas of Europe is indispensable for comparative studies dealing with such questions as biogeography and history of the formation of Arctic and alpine biota, taxonomic composition and degree of specificity of Arctic-alpine fungus flora.

Within Europe, relatively comprehensive data are available especially from the Alps and the Scandinavian mountains (e.g. Favre 1955; Bruchet 1970; Gulden and Lange 1971; Bon 1986; Kühner and Lamoure 1986; Vesterholt 1989, 2005). In addition to these traditional studies European Arctic-alpine fungal communities have been studied by high throughput sequencing (e.g. Bjorbækmo et al. 2010, Fujiyoshi et al. 2011, Lentendu et al. 2011, Geml et al. 2012, Botnen et al. 2014). Also the Arctic region of Greenland has been relatively well studied mycologically (Borgen et al. 2006).

Although the Carpathians are known as an important European diversity hot spot and center of endemism (Pawłowski 1970, Ronikier 2011, Bálint et al. 2011) and to harbor ancient, relic lineages of Arcticalpine plants (e.g. Ronikier et al. 2012), their Arcticalpine fungus flora remains almost unknown. Some data are available for the highest Carpathian massif, 
the Tatra Mountains (e.g. Pilát 1926, Nespiak 1960, Fellner and Landa 1993). Recently data on fungi also have been reported from the southern Carpathians where the largest surface of the alpine zone occurs (Ronikier 2008). However, no wide-ranging analysis has been conducted to date. Here we focus on the genus Hebeloma and report on results of $11 \mathrm{y}$ observations conducted in the alpine zone of all high-mountain massifs of the Carpathians.

Hebeloma is one of the important genera in Arcticalpine habitats (Gardes and Dahlberg 1996, Timling and Taylor 2012). Hebeloma spp. are ectomycorrhizal (Marmeisse et al. 1999). Many species are well known as alpine (and Arctic) specialists, occurring in such habitats with Salix spp. and Dryas spp. (Bruchet 1970, Vesterholt 2005, Eberhardt et al. 2015). Only two Hebeloma species (viz. H. marginatulum, $H$. bruchetii) were reported previously from the alpine belt of the Carpathians (Bruchet 1970, Fellner and Landa 1993), both of them from localities in the Tatra Mountains. No records of Hebeloma species from other parts of the alpine belt of the Carpathians are available. The aim of this study is to assess the diversity of Hebeloma species in the alpine belt of the Carpathians based on morphological and molecular analysis of specimens collected during the first long-term survey and to compare, as far as we can, the diversity of Hebeloma spp. in the highly fragmented alpine zone of the Carpathians with that in the more continuous alpine area of the Alps.

In this paper the distribution of species in other alpine and Arctic regions is discussed partially based on literature data but given the confusion that has existed with regard to species delimitation in the genus (e.g. Vesterholt 2005), we also provide information on species distribution based on our experience of collections examined morphologically and phylogenetically. We detail our collections and describe two new species collected in the Carpathians during this project, and also provide a key to the species of $H$. sect. Hebeloma from Arctic-alpine habitats in Europe.

\section{MATERIALS AND METHODS}

Description of study area and collection of material. - The Carpathians are one of the most important European mountain ranges, and lie east of the Alps and north of the mountains of the Balkan Peninsula. They are divided into three biogeographical sections: western, eastern and southern Carpathians, each composed of several well-delimited massifs bearing their own proper names (e.g. the Tatra Mountains, the highest Carpathian massif reaching an elevation of $2655 \mathrm{~m}$ ). The Carpathians are built of crystaline schist, volcanic and metamorphic rocks with granite intrusions and limestone deposits (Kondracki 1978). Vegetation in the alpine belt of these mountains is diverse and shaped mainly by geological features and microclimatic conditions. On limestone, dolomite and mylonite (non-calcareous) bedrock various plant communities with Dryas octopetala and Salix reticulata as dominant ectomycorrhizal plant species develop on shallow, humus-enriched soils containing a large proportion of gravel. Another important ectomycorrhizal plant species, $S$. herbacea, occupies snow bed and snow field vegetation developed on silicate bedrock where snow persists for a long time, as well as the most exposed localities on silicate crests with shallow and acid soils. Salix retusa s.l., including S. kitaibeliana, is common in rock, scree and stony grassland habitats. Helianthemum spp. occur on neutral to basic soils in various plant communities, whereas Kobresia myosuroides and Salix alpina are important to a lesser extent in the Carpathian alpine belt (Kliment and Valachovič 2007, Ciocârlan 2009). Finally Bistorta vivipara is the most ubiquitous herbaceous ectomycorrhizal species occurring in various altitudinal belts, bedrocks and plant communities.

Material for this study was collected within the framework of a project carried out by one of us (AR) devoted to mycological inventory of the alpine belt of the Carpathians, during 11 vegetation seasons (2002-2012) at more than 350 localities in almost all Carpathian massifs with an alpine belt. Because of difficult access to most alpine areas of the Carpathians (lack of roads and other infrastructure) the localities were visited irregularly. Some sites were visited only once, while others, more easily accessible and with the best developed alpine area (e.g. Bucegi Mountains, parts of the Făgăraş Mountains, the Tatra Mountains) were visited several times. The Carpathian massifs where specimens of Hebeloma were collected are illustrated (FIG. 1). Those massifs visited during field work, within which no Hebeloma specimens were found (the Cindrel Mountains, Ceahlău Mountains, Iezer-Papuşa Mountains, Lotru Mountains, Latoriţei Mountains and Piatra Craiului Mountains in the southern Carpathians and Rodnei Mountains in the eastern Carpathians) are not highlighted in the map. At each site collections were photographed (in most cases) and placed in plastic boxes. Pieces of lamellae were placed in the CTAB buffer (Largent and Baroni 1988) for use in further molecular analysis. All important characters were noted the same day or at the latest the next day in daylight (for a comparable description of colors). Immediately after description the collections were put in plastic bags with silica gel for drying. Of the more than 1300 specimens of fungi collected during field work, the genus Hebeloma was represented by 44 collections found at 27 localities in these Carpathian massifs: the Tatra Mountains and Nízke Tatry Mountains in the western Carpathians, Bucegi Mountains, Făgăraş Mountains, Parâng Mountains, Builă-Vănturariţa Mountains and the Retezat Mountains in southern Carpathians (FIG. 1). In addition, a relic population of Dryas octopetala, a key Arctic-alpine mycorrhizal dwarf shrub, growing in a pine forest in a low massif of Slovenský Raj (almost $800 \mathrm{~m}$ ) was studied. The collections are deposited at the Herbarium of the Polish Academy of Sciences (KRAM) in Krakow. Each collection also has a H.J. Beker (HJB) Database Record number; these are also cited in that we intend to publish this database and we think these numbers therefore will be useful for future researchers. 


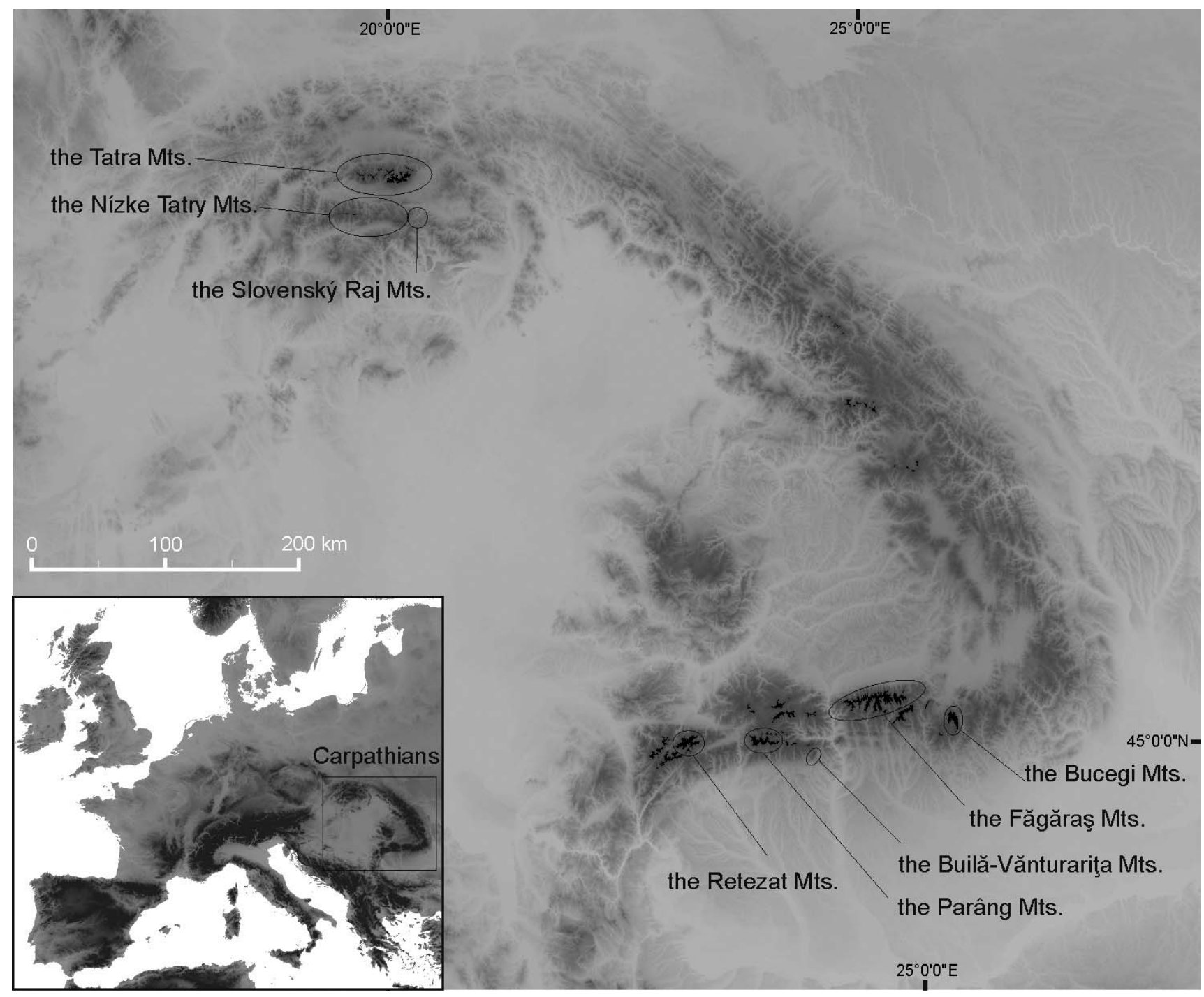

FIG. 1. The Carpathians with the localization of the visited Carpathian massifs. Black area $=$ alpine belt.

Molecular analyses. - Sequence data of the ITS (ITS1-5.8SITS2, internal transcribed spacers of the nuc rDNA) were obtained for all collections. For a selection of collections DNA sequences of the partial RPB2 (encoding the second largest subunit of RNA polymerase II) and TEF1a (translation elongation factor 1- $\alpha$ ) genes also were obtained. In addition to sequences from the Carpathian collections sequences of the same or closely related taxa and $H$. crustuliniforme (in the sense of Vesterholt et al. 2014), H. cylindrosporum, H. sinapizans, and $H$. theobrominum, that is types or representatives of the main sections of Hebeloma according to Vesterholt (2005), were included in the analyses.

Details of DNA extraction, ITS and RPB2 PCR and sequencing primers have been provided (Ronikier and Ronikier 2011, Eberhardt 2012, Eberhardt et al. 2013). PCR and sequencing primers for partial TEFla sequences (forward elo31 m, 5'-TTC ATC AAG AAC ATG ATC AC-3' and reverse a 1 : 1 mix of elo33R_R, 3'-GAC GTT GAA RCC RAC RTT GTC-5' and elo33_W, 3'-GAC GTT GAA WCC
RAC RTT GTC $-5^{\prime}$ ) were constructed based on results of Stielow et al. (2014). PCR reactions were done with Bioline (London, UK) MyTaq and annealing temperatures of 48 C. Raw sequence data were edited in Sequencher 4.9, Gene Codes Corp., Ann Arbor, Michigan). Indels and ambiguous base calls in corresponding positions of forward and reverse traces were regularly encountered in sequences from nuclear ribosomal and protein-coding loci. For sequence reads where length deviant variants occurred, which was observed in all three loci on occasion, the consensus sequence with the lowest number of ambiguous positions was used.

Sequence alignments were done in Mafft 7 as implemented on http://mafft.cbrc.jp/alignment/software/, with EINS-i option. Maximum likelihood analyses were done as heuristic searches in RAxML (8.1.2, Stamatakis 2014), including bootstrap analyses, with the number of replicates determined by the MRE option. Concatenation of alignments was done in SequenceMatrix (Vaidya et al. 2011). Before the concatenation of different datasets, their compatibility 
was tested following the principle of Kauff and Lutzoni (2002), which assumes a conflict to be significant if two relationships for the same set of taxa, one being monophyletic and the other nonmonophyletic, are supported by bootstrap greater than $70 \%$.

Maximum likelihood searches for tree building were carried out locally with 100 (ITS) or 10 (RPB2, TEF1a, concatenated data) replicates with the GTRGAMMA model, selecting the best result for each analysis. Fast bootstrap searches were done locally or on the CIPRES server (Miller et al. 2010) using the MRE option. Trees were visualized with FigTree 1.4.0 (Rambaut 2012). The assignment of collections and sequences to species follows morphology. The taxonomic backbone for this study is provided by Vesterholt (2005), whom we follow with respect to the infrageneric classification.

Morphological analysis.-Morphological analysis was carried out with the help of a Biolomics-based database system (7, www.bio-aware.com). Whenever possible macroscopic information was collected in field notes and input as parametric data.

All microscopic measurements were made with a Leica DMRXA2 microscope system with a Leica DC300 camera (without color filters and with a halogen light source, usually using differential interference contrast) connected to a computer running Leica IM1000 image capture software and Leica QWin image analysis software. Photographs of all relevant features were taken, and all measurements and analysis were carried out with the image analysis software, fed into spreadsheets, where statistics were calculated, and automatically transferred into the database. An advantage of this approach is that all measurements are repeatable and all information relating to these measurements, including all photographs, is stored with the rest of the collection information on the database.

For each collection at least 50 spores were measured in Melzer's reagent, excluding the apiculus. The maximum length and width of each spore was measured and its $Q$ value (ratio of length to width) calculated. Average length, width and $Q$ value were calculated and recorded along with the median, standard deviation and $5 \%$ and $95 \%$ percentiles. The assessment of spore characters follows Vesterholt (2005): spore ornamentation on a scale from O0 (smooth) to $\mathrm{O} 4$ (ornamentation fairly strong and always visible without immersion), the loosening of the perispore P0 (not loosening) to P3 (strongly and consistantly loosening) and the dextrinoidity of the spores in Melzer's reagent from D0 (indextrinoid) to D4 (strongly dextrinoid, immediately becoming dark brick to dark reddish brown).

The average width of the cheilocystidium apex appears to be an important character in the separation of species within Hebeloma (Vesterholt 2005). It is also important, when determining the average apex width, not to be selective with regard to the cystidia chosen for measurement. To determine the average width at the apex, approx. 100 cheilocystidia were measured. These were measured while still on the lamella edge and by measuring all cystidia where the apex could be properly focused and measured. For other measurements at least 20 cheilocystidia, separated from the lamella edge, were measured from each collection. Because of the complex shapes of the cheilocystidia four measurements were made: length, width at apex (A), width at narrowest point in central region $(\mathrm{M})$ and maximum width in lower half (B). The measurements are in this order, including $5 \%$ and $95 \%$ percentiles and median (only for the apex), and an average value was calculated for each of these measurements. Further the ratios $\mathrm{A} / \mathrm{M}, \mathrm{A} / \mathrm{B}$ and $\mathrm{B} / \mathrm{M}$ are calculated for each cystidium and then these are averaged. The measurements were made in $5 \% \mathrm{KOH}$.

The key to species of Hebeloma sect. Hebeloma occurring in the alpine belt was built on the database as a set of complex queries. At the time of writing we have analysed 118 alpine collections (and an additional 151 Arctic collections) belonging to H. sect. Hebeloma out of some 4500 collections of Hebeloma, including their collection details and ecology. For most collections, morphometric parameters were obtained. By having all data fully parameterized, collections can be compared with ease and database queries can be used to isolate those collections with similar features. This in turn enables keys to sections and to species to be built and to be continually tested across a large number of collections.

\section{REsUlts}

We obtained ITS sequences for all collections cited below and RPB2 and TEF1a sequences for Arctic or alpine members of $H$. sect. Hebeloma. Sequence data were submitted to GenBank (KT071011-KT071107, SuPPLEMENTARY TABLE I). Alignments were submitted to TreeBASE (S17371). Topologies (FIG. 2) are unrooted and are displayed according to results (Boyle et al. 2006 unpubl), using Hymenogaster, Naucoria, Galerina and Gymnopilous sequences as outgroup.

A total of 11 species of Hebeloma were collected in the Carpathians. (Fig. 2A), belonging to H. sects. Denudata, Hebeloma, Myxocybe, Velutipes following Vesterholt (2005). Hebeloma naviculosporum previously had not been classified to section.

Hebeloma alpinum is paraphyletic in relation to $H$. aanenii and $H$. crustuliniforme, the other included members of $H$. subsect. Denudata. The species $H$. aanenii is monophyletic but does not receive bootstrap support. Hebeloma vaccinum, another member of $H$. sect. Denudata, but not of $H$. subsect. Denudata sensu Eberhardt et al. (2015), forms a sister clade to $H$. subsect. Denudata clade. Hebeloma laterinum and H. cylindrosporum, both members of $H$. sect. Myxocybe form a joint clade and are well supported. Hebeloma velutipes, $H$. sinapizans, $H$. theobrominum and $H$. naviculosporum - the former three single representatives of their sections and the latter not included in Vesterholt (2005) -form well supported "species" clades, which are outside any of the indicated "section" clades (Fig. 2A). Hebeloma sect. Hebeloma receives high bootstrap support based on ITS, but the Arctic or alpine species included in this tree other than H. nigellum (not recorded from the Carpathians) do not. Because we have only a single 
collection of $H$. grandisporum we do not know whether this species is monophyletic and supported.

The remaining phylogenies (FIG. 2B-D) were inferred only for Arctic-alpine members of $H$. sect. Hebeloma. In the RPB2 topology all species are monophyletic and all but $H$. mesophaeum are well supported (Fig. 2B). In the TEF1a result (FIg. 2C) H. oreophilum and $H$. nigellum are not resolved. In addition, H. mesophaeum is paraphyletic in relation to the highly supported clade of $H$. dunense. There is no conflict between the topologies of the three loci used with respect to species clades; potential conflicts pertaining to the relationship of the species among each other cannot be detected in unrooted phylogenies but are irrelevant for the question at hand. The results of the concatenated data are displayed (FIG. 2D). Here all species appear monophyletic but again $H$. mesophaeum does not receive support and $H$. oreophilum is monophyletic and supported $(75 \%)$, but it does receive high support (FIG. 2B) (RPB2). As before we cannot know whether $H$. grandisporum would be monophyletic in this setting.

\section{TAXONOMY}

Eleven species are recognized in the studied material of which three are Arctic-alpine specialists. Both of the two newly described taxa, $H$. grandisporum and $H$. oreophilum, were collected from alpine habitats. The list of species is arranged in alphabetical order.

Hebeloma aanenii Beker, Vesterh. \& U. Eberh.

Figs. 3, 4A

Specimens examined: SLOVAKIA. ŽILINA: western Carpathians, Nízke Tatra Mountains, Mount Velky Bok, summit area, N48.9402780, E19.8813800, 1720 $\mathrm{m}$, in meadow, among moss, Salix sp. and Bistorta vivipara, 10 Sep 2006, A. Ronikier, S. Adamč́k, V. Kučera, V. Kautman (KRAM F-47190, Database Record HJB13120).

Comment: This recently described species is known so far from Europe and New Zealand where it grows in various habitats and forms mycorrhizae with a wide range of trees or shrubs including Dryas (Eberhardt et al. 2015). The Carpathian alpine collection is typical albeit with basidiome size at the lower end of the range for the species. For a description see Eberhardt et al. (2015). Hebeloma aanenii normally can be distinguished from $H$. alpinum, $H$. vaccinum and related taxa of sect. Denudata based on ITS data (Eberhardt et al. 2015). A description of $H$. aanenii and a key to $H$. subsect. Denudata was studied by Eberhardt et al. (2015).

Hebeloma alpinum (J. Favre) Bruchet $\quad$ Figs. 3, 4B
Specimens examined: ROMANIA. PRAHOVA: southern Carpathians, Bucegi Mountains, Munţele Caraiman, calcareous rocks near the marked trail to Mount Caraiman, N45.4141670, E25.4927700, 2400 m, in meadow among Dryas octopetala, $26 \mathrm{Jul} \mathrm{2004,} \mathrm{M.}$ Ronikier, A. Ronikier, J. Cieślak (KRAM F-46670, Database Record HJB13110); N45.4147220, E25.4927700, 2330 $\mathrm{m}$, in meadow, among moss, D. octopetala and B. vivipara, 1 Aug 2006, M. Ronikier, A. Ronikier, H. Knudsen (KRAM F-46666, Database Record HJB13112). VÂLCEA: southern Carpathians, Builă-Vănturariţa Mountains, S crest of Munţele Builă, N45.2405560, E24.0927780, $1815 \mathrm{~m}$, among Helianthemum sp., 28 Aug 2009, A. Ronikier, M. Ronikier (KRAM F-57432, Database Record HJB14244). SLOVAKIA. PREŠOV: western Carpathians, Tatra Mountains, Belanské Tatra Mountains, Hlúpe Sedlo pass, N49.2388890, E20.2277780, 2000 m, in meadow among D. octopetala, 19 Aug 2006, A. Ronikier, M. Ronikier (KRAM F-46669, Database Record HJB13118); N-E slopes of Mount Ždiarska Vidla (Plačlivá Skála), N49.2447220, E20.2094400, 2070 m, in meadow among D. octopetala, $23 \mathrm{Jul}$ 2007, A. Ronikier, S. Adamčk (KRAM F-47192, Database Record HJB13123); between Vyšné Kopské Sedlo pass and Kopské Sedlo pass, N49.2327780, E20.2191670, 1850 m, among D. octopetala, 17 Sep 2009, A. Ronikier, S. Adamčk (KRAM F-57424, Database Record HJB14236); Jatky crest, N49.2372220, E20.2327780, 2025 m, among D. octopetala and S. reticulata, 3 Aug 2010, A. Ronikier, P. Mleczko (KRAM F-57434, database record HJB14247).

Comment: This Arctic-alpine species is associated mainly with Salix, known from European mountains and Arctic regions also outside Europe (Eberhardt et al. 2015). The Carpathian alpine collections are typical but include one collection with Helianthemum, an associate that we have not seen recorded elsewhere. For a description and a key to $H$. subsect. Denudata see Eberhardt et al. (2015). Eberhardt et al. (2015) were not able to find a single molecular locus that always distinguishes $H$. alpinum from related taxa, but when using several loci all other species can be distinguished from $H$. alpinum.

Hebeloma dunense L. Corb. \& R. Heim Figs. 3, 4C. Specimens examined: POLAND. MAŁOPOLSKA: western Carpathians, Tara Mountains, western Tatra Mountains, Kasprowy Wierch Massif, Mount Beskid, summit area, N49.2302780, E19.9894400, $1900 \mathrm{~m}$, in meadow, 29 Jul 2002, H. Knudsen, A. Ronikier (KRAM F-53052, database record HJB13107; KRAM F-53053, Database Record HJB13108); N slopes of Mount Ciemniak, summit area, N49.2311111, E19.9033330, 2088 m, among S. reticulata, 2 Aug 2010, A. Ronikier, P. Mleczko (KRAM F-57434, database record HJB14246). ROMANIA. SIBIU: southern Carpathians, Fagaraş Mountains, 
A

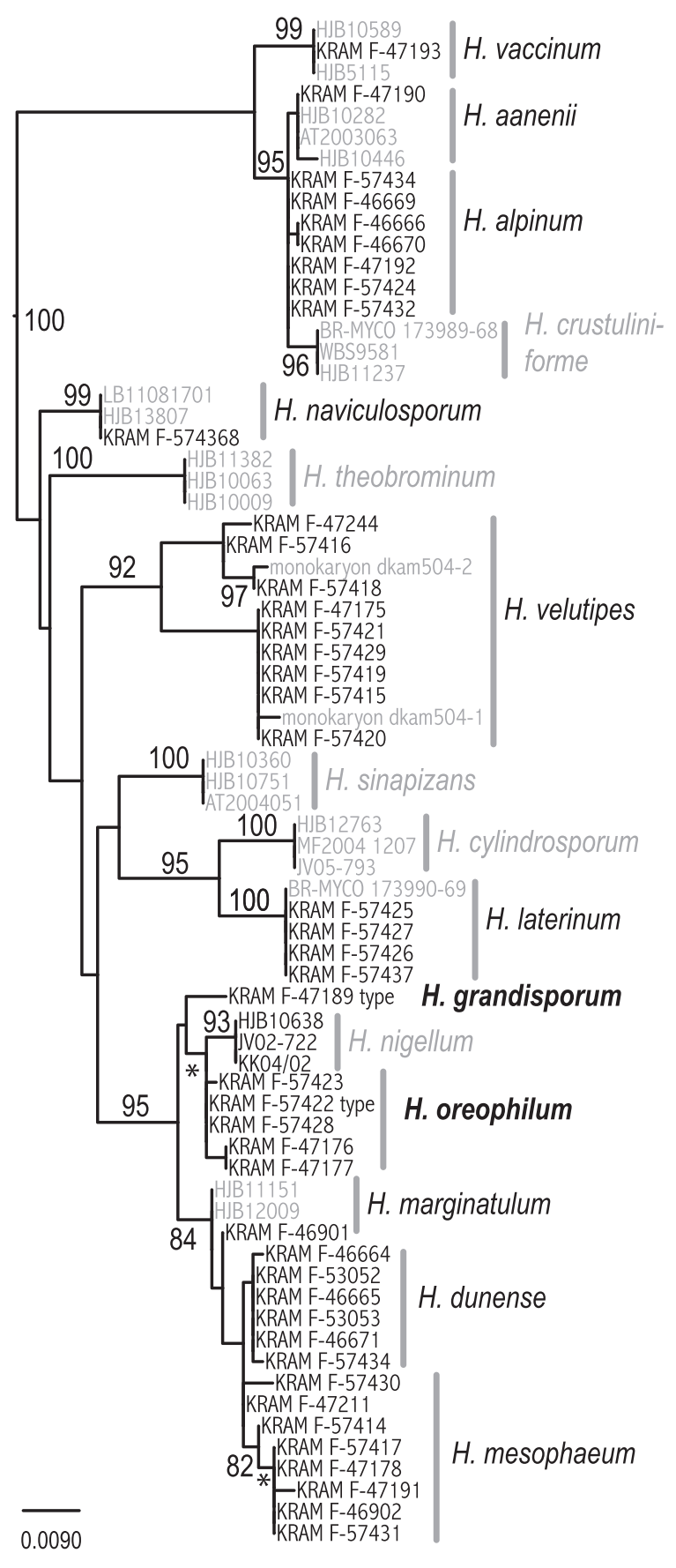

B KRAM F-47189 type H. grandisporum
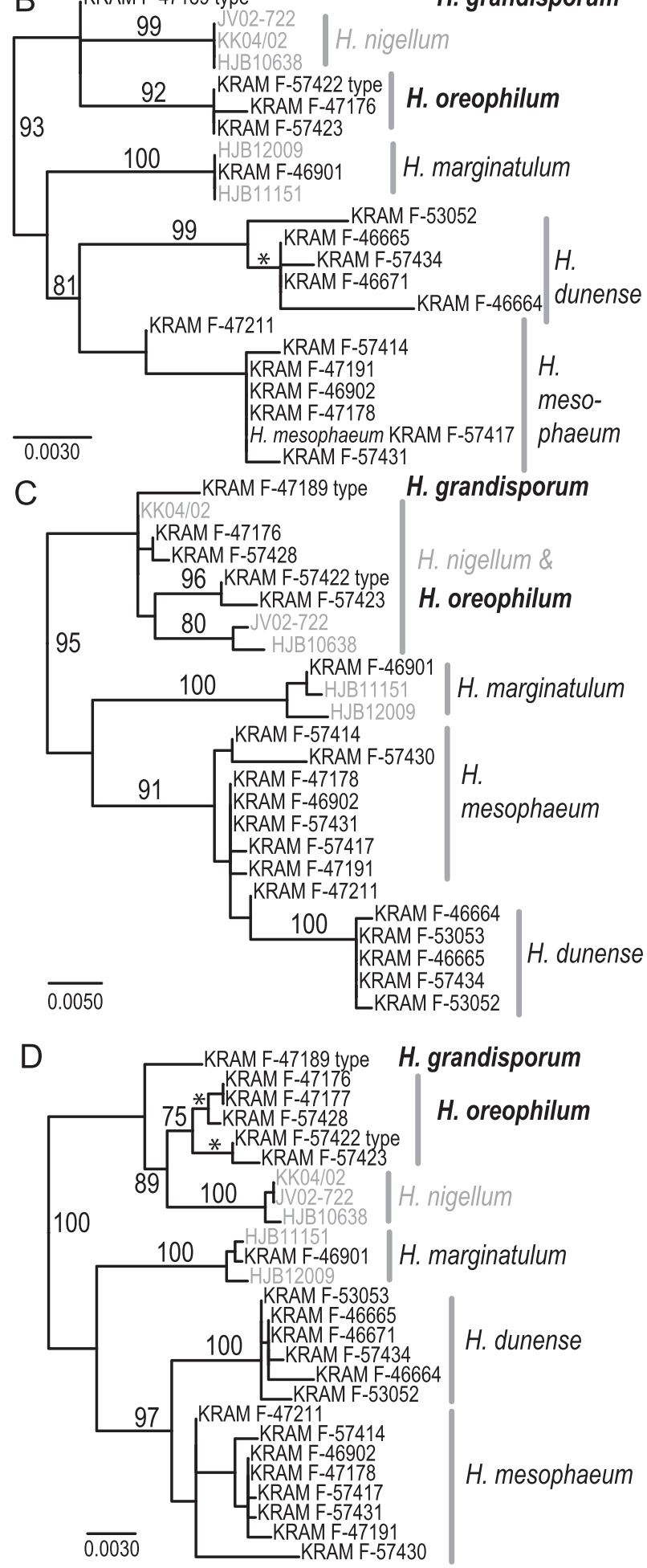

FIg. 2. Maximum likelihood results. H. - Hebeloma. The infrageneric classification where indicated follows Vesterholt (2005). Collections and species names in gray have not been collected in the study area. Bootstrap values $\geq 75 \%$ are shown. Asterisk indicates bootstrap support of $\geq 75 \%$ within species clades. A. Unrooted ITS topology, with support values of 550 bootstrap replicates. For $H$. velutipes, sequences of two monokaryotic strains produced from a single-spore deposit (Aanen and Kuyper 2001) were included. B. Unrooted RPB2 topology of H. sect. Hebeloma, with support values of 1000 bootstrap replicates. C. Unrooted TEF1a topology of $H$. sect. Hebeloma, with support values of 1000 bootstrap replicates. D. ITS, RPB2 and TEF1a concatenated; unrooted topology with 700 bootstrap replicates. 


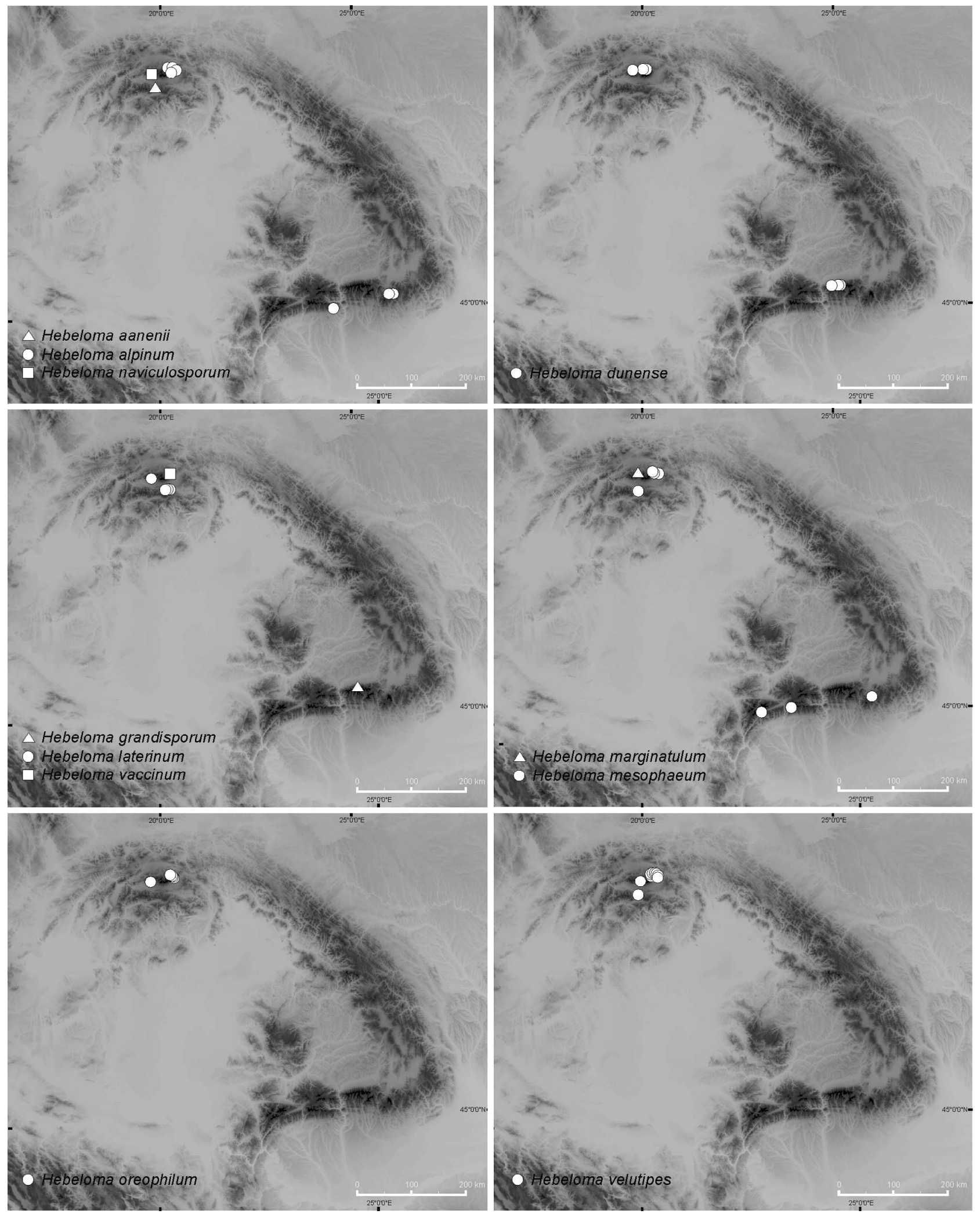

FIG. 3. Distribution maps of Hebeloma species found in the alpine belt of the Carpathians. Black area $=$ alpine belt. 

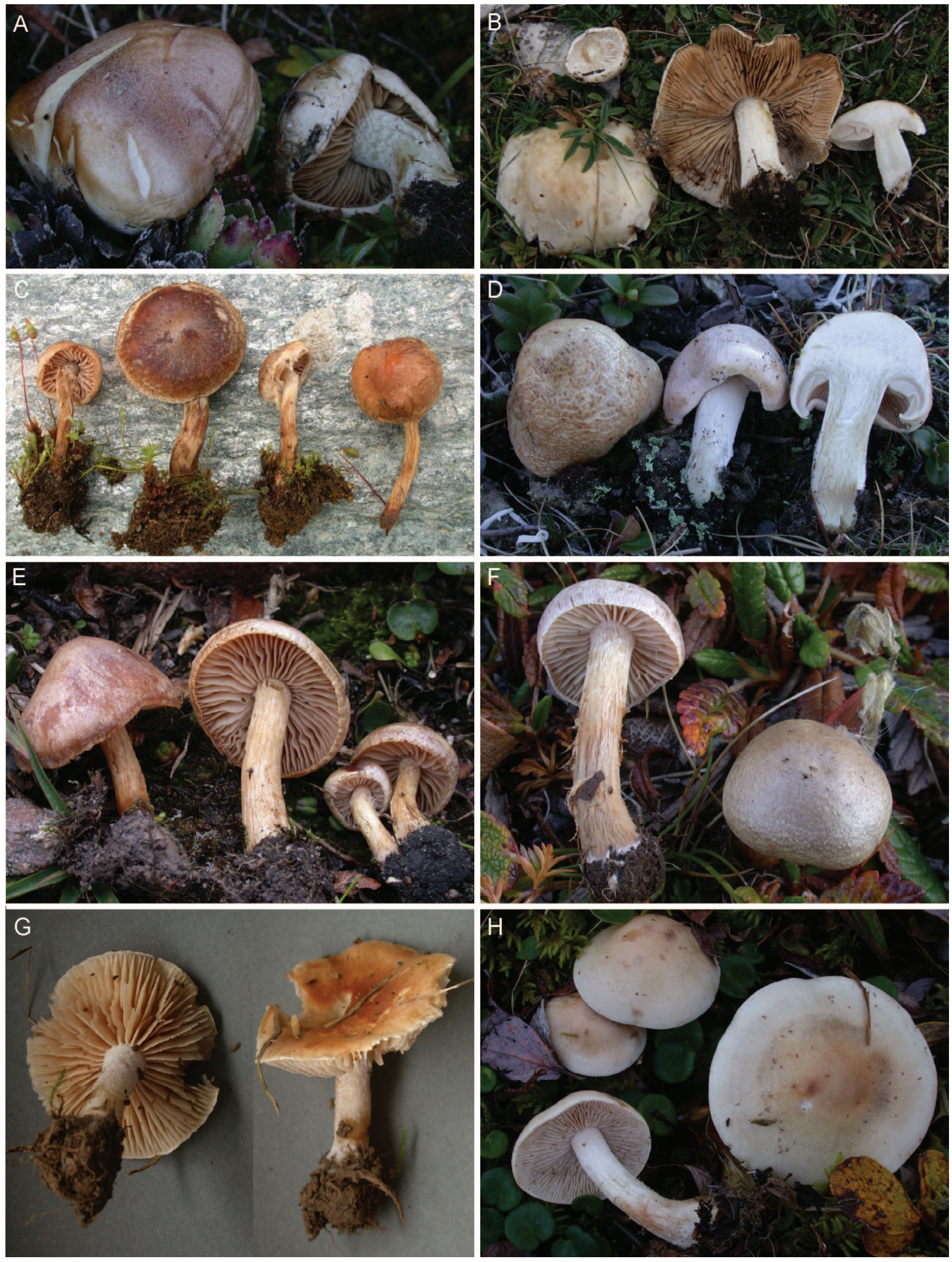

Fig 4. Hebeloma collections from the alpine belt of the Carpathians. A. H. aanenii (KRAM F-47190). B. H. alpinum (KRAM F57432). C. H. dunense (KRAM F-46664). D. H. laterinum (right, cut basidiome; KRAM F-57427) and H. naviculosporum (left; KRAM F-57436). E. H. marginatulum (KRAM F-46901). F. H. mesophaeum (KRAM F-57417). G. H. vaccinum (KRAM F-47193). H. H. velutipes (KRAM F-57421). 
upper part of Valea Podragului valley (toward Şaua Podragului Pass), N45.6047220, E24.6883300, 2270 m, among S. retusa, 5 Aug 2004, M. Ronikier, A. Ronikier (KRAM F-46665, database record HJB13111); the pass in the N-NW ridge of the Arpaşu Mare Massif, E facing slopes (blue hiking trail), N45.6061110, E24.6725000, $2100 \mathrm{~m}$, among moss, S. reticulata and S. retusa, 28 Jul 2006, M. Ronikier, A. Ronikier (KRAM F-46664, database record HJB13115); Mount Paltinului, summit area, N45.5986110, E24.6066600, $2410 \mathrm{~m}$, in meadow, among S. reticulata, 4 Aug 2006, H. Knudsen, A. Ronikier, M. Ronikier (KRAM F-46671, Database Record HJB13116).

Comment: The species occurs with Salix in bogs and sand dunes (Vesterholt 1989, 2005). While we know this species to be common in alpine and Arctic habitats, as far as we are aware, this is the first published report of the fungus from the alpine belt. The Carpathian alpine collections are variable in size, color and presence of veil remnants (from almost absent to conspicuous). For a description see Vesterholt (2005) where it is described under the name Hebeloma collariatum Bruchet. Hebeloma dunense is a member of $H$. sect. Hebleoma and is monophyletic in all topologies (FIG. 2).

Hebeloma grandisporum Beker, U. Eberh. \& A. Ronikier, sp. nov. Figs. 3, 5, 6

MycoBank: MB812871

Typification: ROMANIA. SIBIU: southern Carpathians, Fagaraş Mountains, upper part of Valea Podragului Valley (toward Şaua Podragului Pass), N45.6047220, E24.6883300, $2270 \mathrm{~m}$, among Salix retusa, 25 Jul 2006, M. Ronikier, A. Ronikier (holotype KRAM F-47189). Database record HJB13114).

Etymology: From Grandis (Latin) = large and sporum $($ Latin $)=$ spore.

Diagnosis: Hebeloma grandisporum belongs to $H$. sect. Hebeloma based on the presence of a cortina and the lageniform or ventricose cheilocystidia. It has consistently two-spored basidia and large amygdaloid and limoniform spores (ave. $15.4 \times 8.9 \mu \mathrm{m}$ ), which are strongly dextrinoid. The ITS of the species is distinct from ITS sequences of all known species of Hebeloma from Europe.

Basidiomes in scattered group. Pileus small, up to $20 \mathrm{~mm}$ diam, convex to umbonate, sometimes broadly; surface slightly viscid, tacky when moist occasionally spotting never hygrophanous; cuticle cream or warm buff to Isabella or yellowish brown or cinnamon, paler toward the margin which is cream; pileus margin usually straight becoming upturned with age. Lamellae emarginate to adnate, distant to subdistant $(\mathrm{L}=24)$; cream, alutaceous or brown when young, later umber to sepia following spore maturity; edge fimbriate, paler than lamella surface; droplets on the lamella edge are not present; lamellulae frequent. Stipe central, cylindrical to clavate; white or alutaceous, rarely discoloring from the base; surface dry, usually fibrillose, occasionally more pruinose or velute; interior stuffed when young but sometimes becoming hollow with age. Cortina present. Flesh thin, cream or pale brown. Odor raphanoid. Flavor not recorded. Spore deposit not recorded. Exsiccata dark and firm.

Spores amygdaloid, sometimes limoniform, with small apiculus and rounded at the end opposite the apiculus, with a distinct thinning of the spore wall and a distinct papilla; some spores guttulate with one or more oily drops, weakly ornamented with no sign of a loosening perispore and strongly dextrinoid becoming orange-brown (O2; P0; D3); spore under the microscope pale brown; spores based on 51 specimens 14.0-16.5 × 8.5-9.5 $\mu \mathrm{m}$, with median $15.5 \times$ $9.0 \mu \mathrm{m}$ and ave. $15.4 \times 8.9 \mu \mathrm{m}$ with $\mathrm{S}$. D. length 0.83 $\mu \mathrm{m}$ and width $0.42 \mu \mathrm{m}, \mathrm{Q}$ value $1.56-1.84$, with median 1.73 and ave. 1.72 with S. D. 0.09. Basidia cylindrical to clavate and two-spored, 31-44 × 7.0-9.5 $\mu \mathrm{m}$, with ave. $36 \times 8.4 \mu \mathrm{m}$. Pleurocystidia not found. Cheilocystidia lageniform or ventricose and occasionally septate or knee-shaped; width of apex range 5.0-7.0 $\mu \mathrm{m}$, with median $6.0 \mu \mathrm{m}$ and ave. $5.8 \mu \mathrm{m}$ with S.D. $0.66 \mu \mathrm{m}$; based on 23 cheilocystidia the ranges are 34-53 $\times$ $5.0-7.0 \times 4.5-6.5 \times 6.0-10.5 \mu \mathrm{m}$ while the averages are $42 \times 5.8 \times 5.6 \times 8.2$. The ave. cheilocystidia ratios were: $\mathrm{A} / \mathrm{M}=1.04 ; \mathrm{A} / \mathrm{B}=0.71 ; \mathrm{B} / \mathrm{M}=1.49$. Caulocystidia resemble cheilocystidia but up to $100 \mu \mathrm{m}$ long. Pileipellis is an ixocutis with epicutis $130 \mu \mathrm{m}$ thick, embedded hyphae up to $5 \mu \mathrm{m}$ broad, smooth or occasionally encrusted, colorless or occasionally pigmented; cutis: brown and made up of cylindrical to isodiametric elements. Trama below the subcutis contains isodiametric elements. Clamp connections present throughout the basidiome.

Habitat: Our single collection of $H$. grandisporum is from the alpine zone of the southern Carpathians in Romania and grew with Salix.

Comment: The presence of a cortina and the lageniform or ventricose cheilocystidia clearly places this taxon in $H$. section Hebeloma. Within this section it can be differentiated on the basis of the large amygdaloid and limoniform spores that are distinctly to strongly dextrinoid. It is the only Hebeloma collection we have ever encountered where all basidia appear to be two-spored, which no doubt contributes to the large spore size. Because we have only a single collection we do not know whether the two-spored basidia are an individual aberration or constant character of the species, as for example, in Lactarius acerrimus, which happens to have the largest spores within its genus in Europe (Heilmann-Clausen et al. 1998). However, because the collection here described as $H$. 
grandisporum is molecularly distinct in all loci tested and therefore presumably also biologically clearly distinct from all other taxa within $H$. sect. Hebeloma, regardless of the number of spores per basidium, we have decided to report it at this time. Molecular data support the inclusion of this species in $H$. sect. Hebeloma.

Hebeloma laterinum (Batsch) Vesterh. $\quad$ Figs. 3, 4D Specimens examined: SLOVAKIA. PREŠOV: western Carpathians, Slovenský Raj Mountains, S-E from Vernárska Tiesňava gorge, N48.9305560, E20.2897220, $790 \mathrm{~m}$, in conifer woodland, among D. octopetala and Pinus sylvestris, 11 Sep 2009, A. Ronikier, M. Ronikier (KRAM F-57425, database record HJB14237, KRAM F57426, database record HJB14238); N 48.9305280, E20.2896670, $785 \mathrm{~m}$, among D. octopetala and $P$. sylvestris, 13 Oct 2010, A. Ronikier, P. Mleczko (KRAM F57437, database record HJB14248). ŽILINA: western Carpathians, Tatra Mountains, western Tatra Mountains, S-E ridge of Mount Baranec, N49.1583330, E19.7569440, $1945 \mathrm{~m}$, among S. retusa, 27 Sep 2009, A. Ronikier, M. Ronikier (KRAM F-57427, database record HJB14239).

Comment: With its short cylindrical cheilocystidia the species belongs in $H$. sect. Myxocybe and a morphological key to that section is provided in Vesterholt (2005). For a description see Vesterholt (2005). This is a woodland species occurring on calcareous soils with both coniferous and deciduous trees (Vesterholt 2005). Bruchet writes (1970) that "Il peut atteindre la zone alpine sous une forme un peu plus petite et trapue". We have examined Bruchet's specimens and Favre's material (1955) and also find that this has a small squat form. Carpathian collections from a relic Dryas octopetala locality from the Slovenský Raj Mountains (forest belt) are typical, while the alpine collection is smaller and squat.

Although macroscopically slightly different from lowland specimens, the alpine collections appear microscopically and molecularly identical to other collections and it therefore is likely that the macroscopic difference is the result of occurrence in the high mountain environment. ITS supports the inclusion of the Carpathian alpine collection into $H$. laterinum (FIG. 2A).

Hebeloma marginatulum (J. Favre) Bruchet FIgs. 3, 4E Specimens examined: POLAND. MAŁOPOLSKA: western Carpathians, Tatra Mountains, western Tatra Mountains, Czerwone Wierchy Massif, Małołącka Przełęcz Pass, E slopes, N49.2355560, E19.9233300, 1930 m, in meadow, among S. herbacea, 24 Aug 2006, A. Ronikier (KRAM F-46901, database record HJB13119).
Comment: This is an Arctic-alpine species associated with Salix (Vesterholt 1989, 2005). The Carpathian alpine collection is typical. For a description see Vesterholt (2005). Whereas this taxon is not monophyletic in the ITS topology, RPB2, TEF1a and the results of the analysis of the concatenated dataset support $H$. marginatulum as monophyletic (FIG. 2).

Hebeloma mesophaeum (Pers.) Quél. Tigs. 3, 4F Specimens examined: ROMANIA. DÎMBOVIŢA: southern Carpathians, Bucegi Mountains, at the Şaua Şugărilor Pass, N45.4316670, E25.4594400, $2400 \mathrm{~m}$, in meadow, among moss and D. octopetala, 27 Jul 2004, M. Ronikier, A. Ronikier (KRAM F-47211, database record HJB13109), 2 Aug 2006, M. Ronikier, A. Ronikier, H. Knudsen (KRAM F-46902, database record HJB13113). HUNDEOARA: southern Carpathians, Parâng Mountains, E slopes of Mount Parângul Mare, below the summit, N45.3416670, E23.5413890, $2412 \mathrm{~m}$, among S. herbacea, 25 Aug 2009, A. Ronikier, M. Ronikier (KRAM F-57430, database record HJB14242); southern Carpathians, Retezat Mountains, E slopes of Piatra Iorgovanului, N45.2831944, E22.8500000, $1985 \mathrm{~m}$, among D. octopetala and $S$. retusa, 22 Aug 2009, A. Ronikier, M. Ronikier (KRAM F-57431, database record HJB14243). SLOVAKIA. ŽILINA: western Carpathians, Nízke Tatra Mountains, Mount Velky Bok, summit area, N48.9402780, E19.8813800, $1720 \mathrm{~m}$, in meadow, among moss, Salix sp. and B. vivipara, 10 Sep 2006, A. Ronikier, S. Adamăk, V. Kučera, V. Kautman (KRAM F-47191, database record HJB13121). PREŠOV: western Carpathians, Tatra Mountains, Belanské Tatra Mountains, Jatky crest, N49.2366670, E20.2358330, 2000 m, in meadow, among moss, D. octopetala and $S$. reticulata, $24 \mathrm{Jul}$ 2007, A. Romikier, M. Ronikier, S. Adamǎk, W. Paul (KRAM F-47178, database record HJB13124); N49.2344440, E20.2469440, $1970 \mathrm{~m}$, among D. octopetala and S. reticulata, 15 Sep 2009, A. Romikier, S. Adamăk (KRAM F-57417, database record HJB14229); W slopes of Mount Bujačí Vrh, N49.2307220, E20.2580560, $1875 \mathrm{~m}$, among D. octopetala and S. reticulata, 15 Sep 2009, A. Ronikier, S. Adamǎk (KRAM F-57414, database record HJB14226).

Comment: This is one of the most common species of the genus in Europe, occurring in various habitats including Arctic and alpine regions with various hosts (Vesterholt 1989, 2005). Some Carpathian collections exhibit a typically bicolored pileus, while others have more uniform colors. For a description see Vesterholt (2005). We have not found any single locus yet that supports $H$. mesophaeum as monophyletic, even though it does receive high support in the analysis of the concatenated dataset (FIG. 2D). We have not been able to find any supported subgroups within this taxon either. Hebeloma mesophaeum is supported as a member of $H$. sect. Hebeloma (FIG. 2A). 


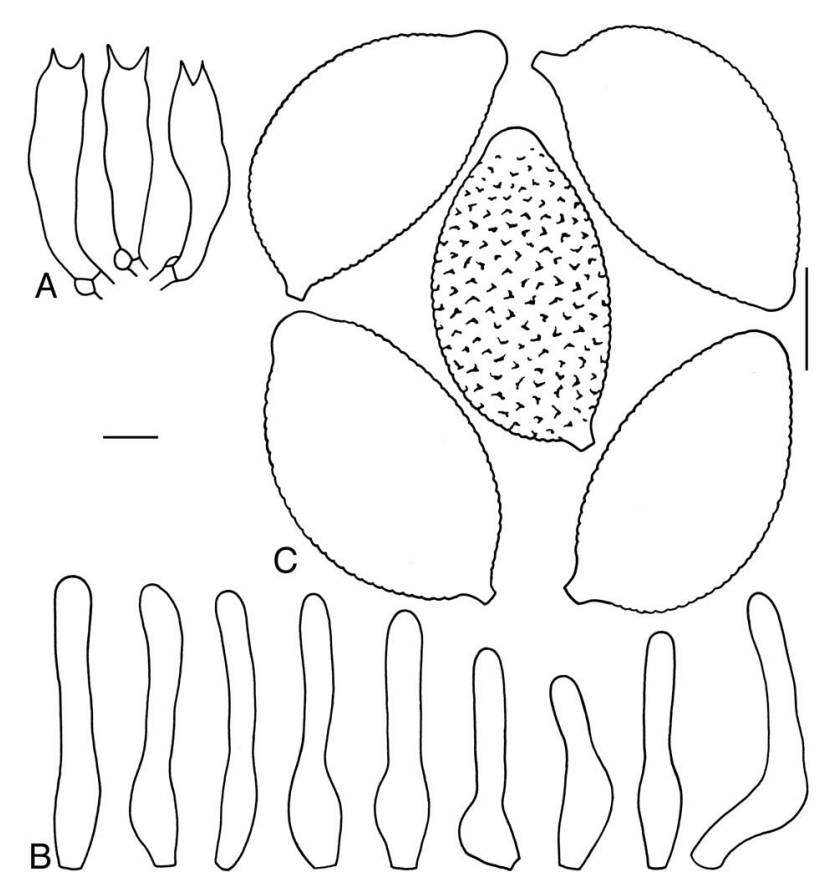

FIG. 5. Line drawing of Hebeloma grandisporum collection KRAM F-47189 (HJB13114) (holotype): A. Basidia $\times 1000$. B. Cheilocystidia $\times 1000$, bar $=10 \mu \mathrm{m}$. C. Spores $\times 1600$, scale bar $5 \mu \mathrm{m}$.

Hebeloma naviculosporum Heykoop, G. Moreno \& EsteveRav.

Figs. 3, 4D

Specimens examined: SLOVAKIA. ŽILINA: western Carpathians, Tatra Mountains, Western Tatra Mountains, S-E ridge of Mouny Baranec, N49.1583330, E19.7569440, $1945 \mathrm{~m}$, among S. retusa, 27 Sep 2009, A. Ronikier, M. Ronikier (KRAM F-57436, database record HJB14568).

Comment: This is a rare species known from the type locality with Pinus sylvestris in Spain and all collections of which we are aware have been recorded with conifer trees. For a description see Heykoop et al. (1992). Typically the pileus has strong orange colors. The pileus surface of the Carpathian collection was cracked into small squamules with some orange pigment but far paler than other collections we have examined. This pale color makes it macroscopically similar to $H$. laterinum with which it co-occurred at the same locality. Hebeloma naviculosporum has cylindrical cheilocystidia and its navicular spores with high length/width ratio distinguish it from all other known European Hebeloma spp. including $H$. laterinum. These differences in morphology of an alpine collection might have been caused by exposure to more extreme conditions than typical for the species, but ITS data support its assignement to $H$. naviculosporum.

Hebeloma oreophilum Beker \& U. Eberh., sp. nov. FIGS. 3, 7-9
MycoBank: MB812872

Typification: SLOVAKIA. PREŠOV: western Carpathians, Tatra Mountains, Belanské Tatra Mountains, $\mathrm{N}$ slopes of Mount Hlúpy, vicinity of the summit, N49.2376390, E20.2222200, $1970 \mathrm{~m}$, on mossy soil among $S$. reticulata and S. retusa, 17 Sep 2009, A. Ronikier, S. Adamčik (holotype KRAM F-57422). Isotype BR 5020184124533. Database record HJB14234.

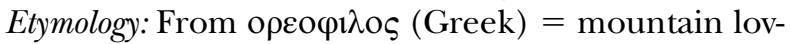
ing, to emphasize its presence in alpine habitats.

Diagnosis: Hebeloma oreophilum has the persisting cortina and the lageniform or ventricose cheilocystidia of $H$. section Hebeloma. The species is similar to H. clavulipes but has wider (ave. 6.8-7.2 $\mu \mathrm{m}$ ) and more ovoid spores and occurs in the alpine habitat.

Basidiomes usually in scattered groups. Pileus up to $40 \mathrm{~mm}$ diam, convex; surface slightly viscid, tacky when moist occasionally appearing hygrophanous; cuticle clay-buff to Isabella to brownish olive or cinnamon, paler toward the margin which is cream to pinkish buff often slightly pruinose or tomentose; pileus margin often involute when young, then straight. Lamellae emarginate, subdistant ( $\mathrm{L}=44-48)$ with a maximum depth of $6 \mathrm{~mm}$; cream, alutaceous or brown when young, later clay-buff following spore maturity; edge fimbriate, paler than lamella surface; droplets on the lamella edge are absent; lamellulae frequent. Stipe central, cylindrical, occasionally slightly clavate, 35-70 $\times$ 3-6 mm; clay-buff, discoloring from the base, which becomes brownish olive, sometimes strongly so, when handled or with age; surface dry, fibrillose, pruinose at apex above cortina; interior stuffed when young but becoming hollow with age. Cortina visible and reasonably persistent. Flesh thick, cream or pale brown. Odor raphanoid. Flavor slightly raphanoid, slightly bitter. Spore deposit color not recorded.

Spores amygdaloid, occasionally ovoid, with small apiculus and rounded at the end opposite the apiculus, with a distinct thinning of the spore wall and a weak papilla, some spores guttulate with one or more oily drops, weakly ornamented to distinctly ornamented, sometimes with some sign of loosening perispore in a few spores and strongly dextrinoid becoming orange-brown (O2,O3; P1; D3); spore under the microscope pale brown to brown; spore size based on 50 spores of the holotype, 10.5-12.0 $\times 6.5-7.5 \mu \mathrm{m}$, with median $11.0 \times 7.0 \mu \mathrm{m}$ and ave. $11.3 \times 6.9 \mu \mathrm{m}$ with S. D. length $0.78 \mu \mathrm{m}$ and width $0.36 \mu \mathrm{m}, \mathrm{Q}$ value 1.47-1.78, with median 1.64 and ave. 1.65 with S. D. 0.14 ; dimensions based on five collections, medians $11.2-12.6 \times 6.7-7.2 \mu \mathrm{m}$ and ave. $11.3-12.7 \times 6.8-7.2$ $\mu \mathrm{m}$ with $\mathrm{S}$. D. length $0.61-1.25 \mu \mathrm{m}$ and width $0.26-$ $0.59 \mu \mathrm{m}$, ave. Q 1.65-1.82. Basidia cylindrical to clavate and four-spored, 28-35 × 6.0-8.5 $\mu \mathrm{m}$, with ave. 29.5$32.5 \times 6.1-8.2 \mu \mathrm{m}$. Pleurocystidia not found. 

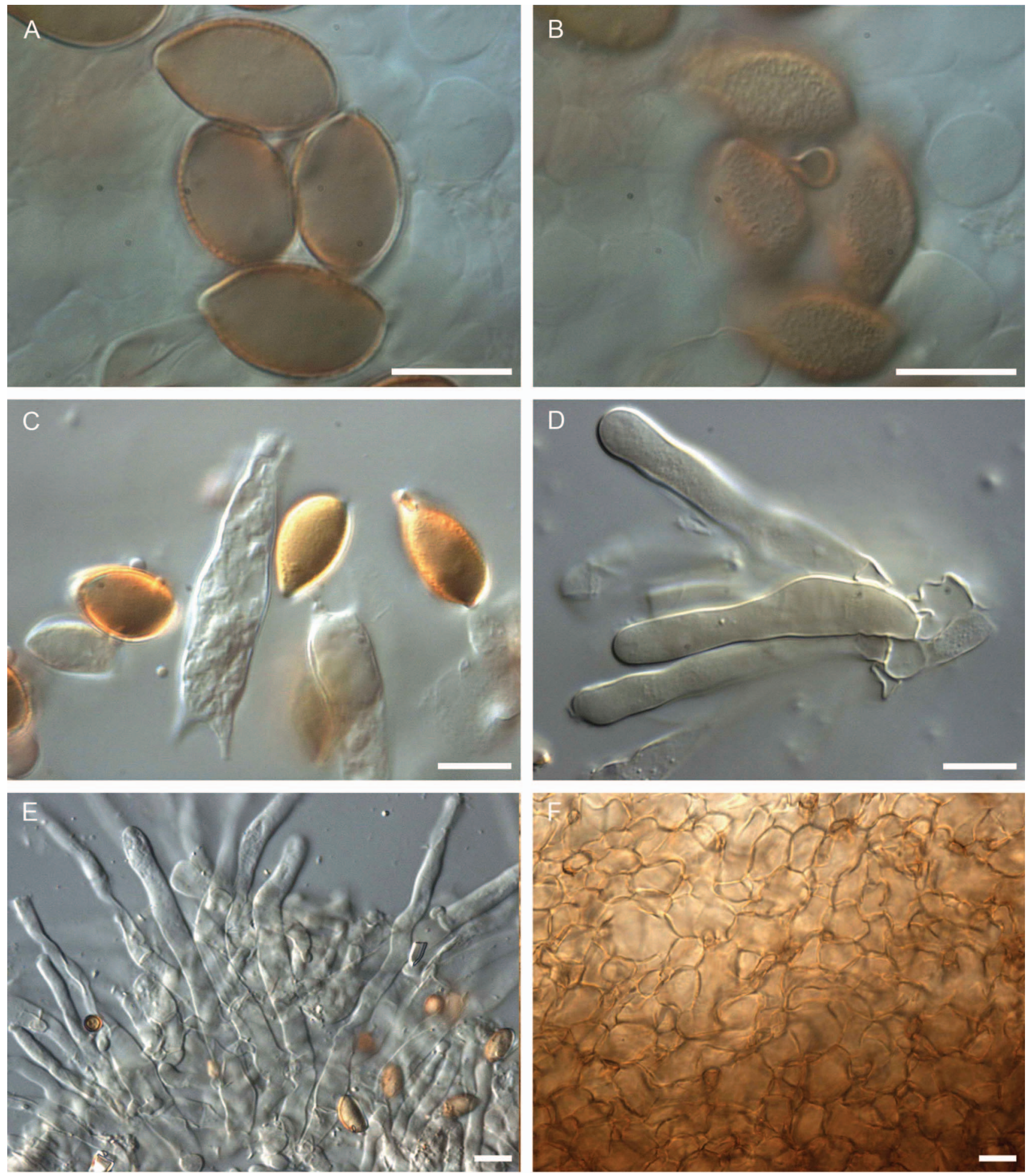

FIG. 6. Hebeloma grandisporum KRAM F-47189 (HJB13114) (holotype): A-B. Spores × 1600 in Melzer's reagent. B. Spore ornamentation. C. Basidium $\times 1000$. D. Cheilocystidia $\times 1000$. E. Caulocystidia $\times 500$. F. Cutis $\times 500$. Bars $=10 \mu \mathrm{m}$. Microographs H.J. Beker.

Cheilocystidia lageniform ventricose, occasionally cylindrical and sometimes with apical thickening, basal thickening, knee-shaped, median thickening, septate; width of apex holotype, 4.0-6.0 $\mu \mathrm{m}$, with median 4.5 $\mu \mathrm{m}$ and ave. $4.8 \mu \mathrm{m}$ with S. D. $0.62 \mu \mathrm{m}$; across five collections median 4.7-5.7 $\mu \mathrm{m}$ and ave. $4.8-5.7 \mu \mathrm{m}$, with at least 20 selected cheilocystidia of five collections $42-66 \times 4.0-6.5 \times 4.0-6.0 \times 7.0-11.0 \mu \mathrm{m}$ while the 
averages are 49-55 × 4.8-5.7 × 4.5-5.3 × 8.2-9.0 and $54 \times 4.8 \times 4.5 \times 8.8 \mu \mathrm{m}$ ave. for the holotype. The ave. cheilocystidia ratios for the five collections were: $\mathrm{A} / \mathrm{M}=1.03-1.24, \mathrm{~A} / \mathrm{B}=0.57-0.67, \mathrm{~B} / \mathrm{M}=1.57-$ 1.94. Caulocystidia resemble cheilocystidia but are less ventricose and more cylindrical, often multiseptate, up to $120 \mu \mathrm{m}$ long. Pileipellis is an ixocutis with a relatively thin epicutis $50-70 \mu \mathrm{m}$, embedded hyphae up to 5-7 $\mu \mathrm{m}$ broad, smooth, colorless or occasionally pigmented; cutis reddish brown and made up of cylindrical to isodiametric elements. Trama below the subcutis contains cylindrical to sausage shaped elements up to $18 \mu \mathrm{m}$ broad. Clamp connections present throughout the basidiome.

Habitat: The five collections of $H$. oreophilum from the western Carpathians of Slovakia were collected within $40 \mathrm{~km}$ of each other. They were recorded from calcareous soil with either Salix reticulata, $S$. retusa or Dryas octopetala. The altitude was 1940-2120 m.

Additional specimens examined: SLOVAKIA. PREŠOV: western Carpathians, Tatra Mountains, Belanské Tatra Mountains, Hlúpe Sedlo Pass, N49.2388890, E20. 2277780, $2000 \mathrm{~m}$, in meadow, among moss and S. reticulata, 19 Aug 2006, A. Ronikier, M. Ronikier (KRAM F-47177, database record HJB13117); N49.2388890, E20.2275000, $1940 \mathrm{~m}$, in meadow, among S. reticulata, 2 Sep 2009, A. Ronikier (KRAM F-47176, database record HJB13126); N slopes of the Mount Hlúpy, vicinity of a summit, N49.2376390, E20.2222200, 1970 m, among S. reticulata and S. retusa, 17 Sep 2009, A. Ronikier, S. Adamčk (KRAM F-57423, database record HJB14235). ŽILINA: western Carpathians, Tatra Mountains, western Tatra Mountains, E slopes of S-E ridge of Mount Baranec, N49.1708330, E19.7472220, 2114 m, on soil among D. octopetala, 27 Sep 2009, A. Ronikier, M. Ronikier (KRAM F-57428, database record HJB14240).

Comment: The persistent presence of a cortina and the lageniform or ventricose cheilocystidia clearly place this taxon in $H$. section Hebeloma. Within this section it can be differentiated on the basis of the amygdaloid and ovoid spores distinctly to strongly dextrinoid, the number of lamellae, which is always at least 40 , and its occurrence in alpine habitats. It is closely related to $H$. clavulipes but can be differentiated from that species not only by the habitat but also by the wider spores $(6.8-7.2 \mu \mathrm{m}$ vs. $5.8-6.6 \mu \mathrm{m})$ which are more ovoid and rarely limoniform (with at most a weak papilla). Molecularly $H$. oreophilum clusters with other members of $H$. sect. Hebeloma. We have not found a single locus that always separates $H$. oreophilum from all other taxa, but within the context of alpine taxa, $H$. oreophilum is monophyletic with $R P B 2$ (support $92 \%$ ) and, with lower support, in the result of the concatenated dataset (FIG. 2B, D).
Hebeloma vaccinum Romagn. $\quad$ Figs. 3, 4G Specimens examined: SLOVAKIA. PREŠOV: western Carpathians, Tatra Mountains, Belanské Tatra Mountains, N slopes of Mount Hlúpy, N49.2369440, E20.2202780, $2050 \mathrm{~m}$, in meadow, among D. octopetala and S. reticulata, $25 \mathrm{Jul}$ 2007, A. Ronikier, S. Adamčik (KRAM F-47193, database record HJB13125).

Comment: This fairly common species occurs in bogs and sand dunes and occasionally in Arctic or alpine habitats under Salix and Populus (Vesterholt 2005). The Carpathian collection is typical in regard to all characters. For a description see Vesterholt (2005). From a morphological viewpoint $H$. aanenii and $H$. alpinum have primarily clavate-stiptate cheilocystidia, which separate them from $H$. vaccinum, which has predominantly clavate-ventricose cheilocystidia. The ITS distinguishes $H$. vaccinum and $H$. cavipes from all other Hebeloma spp.; these two taxa are best separated by $R P B 2$ sequences.

Hebeloma velutipes Bruchet

Figs. 3, 4H

Specimens examined: SLOVAKIA. ŽILINA: western Carpathians, Nízke Tatra Mountains, Mount Vel'ky Bok, summit area, N48.9402780, E19.8813800, 1720 $\mathrm{m}$, in meadow, among moss, Salix sp. and B. vivipara, 10 Sep 2006, A. Ronikier, S. Adamčik, V. Kučera, V. Kautman (KRAM F-47244, database record HJB13122). PREŠOV: western Carpathians, Tatra Mountains, Belanské Tatra Mountains, W slopes of Mount Bujačí Vrh, N49.2307220, E20.2580560, $1875 \mathrm{~m}$, among $D$. octopetala and S. reticulata, 15 Sep 2009, A. Ronikier, S. Adamčk (KRAM F-57415, database record HJB14227, KRAM F-57416, database record HJB14228); Jatky crest, N49.2377780, E20.2319440, $2008 \mathrm{~m}$, among $D$. octopetala, 2 Sep 2008, A. Ronikier (KRAM F-47175, Database Record HJB13127); N49.2344440, E20.2469440, $1970 \mathrm{~m}$, among D. octopetala and S. reticulata, 15 Sep 2009, A. Ronikier, S. Adamčik (KRAM F-57418, database record HJB14230, KRAM F-57419, database record HJB14231); Hlúpe Sedlo Pass, N49.2388890, E20. 2263890, $1920 \mathrm{~m}$, on mossy soil, among S. retusa, 17 Sep 2009, A. Ronikier, S. Adamčik (KRAM F-57420, database record HJB14232, KRAM F-57421, database record HJB14233); High Tatra Mountains, upper part of Mengusovská Dolina Valley, S from Vel'ké Hincovo Pleso lake, N49.1719440, E20.0627780, $1935 \mathrm{~m}$, among D. octopetala and S. retusa, 28 Sep. 2009, A. Ronikier, M. Ronikier (KRAM F-57429, database record HJB14241).

Comment: This is one of the most common species in Europe, which can be found in many different habitats (Vesterholt 2005). In the alpine belt of the Carpathians the fungus is also common and all collections are typical. For a description and keys to $H$. sect. Hebeloma see Vesterholt (2005). Already Aanen and 


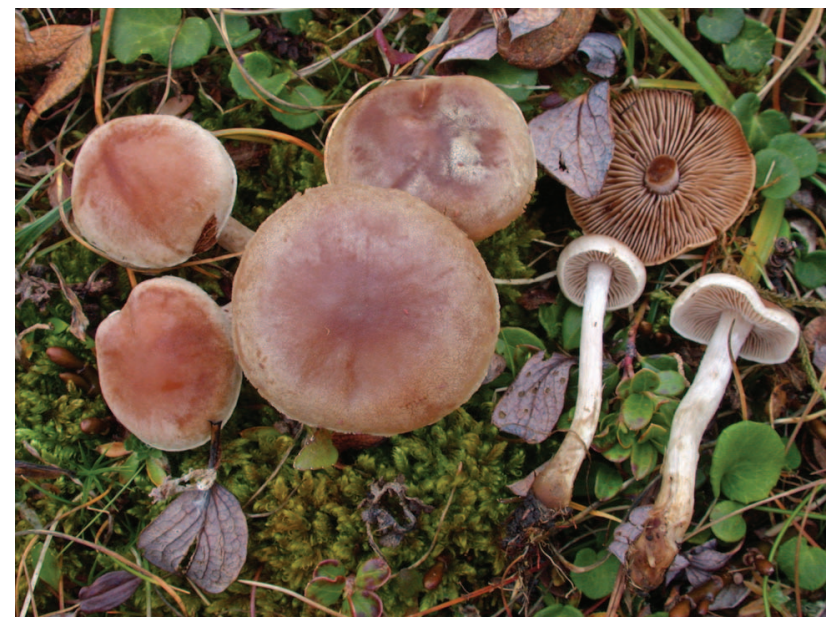

FIG. 7. Hebeloma oreophilum KRAM F-57422 (HJB14234) (holotype). Photograph by A. Ronikier.

co-workers (2001) described that many $H$. velutipes collections (genotypes) show an extraordinary polymorphism in the ITS. Representatives of both genotypes are present in the Carpathian population as demonstrated by the inclusion of ITS sequences (FIG. 2A) of monokaryotic strains gained from single-spore cultures of the spore deposit of a single specimen (Aanen et al. 2001). Intragenomic variation also is common in coding genes (Eberhardt et al. 2013, 2015). As a result $H$. velutipes is difficult to delimit molecularly, at least until a better overview of the full extent of the intragenomic variation is known. From a morphological viewpoint it has primarily gently clavate cheilocystidia that are cheilocystidia that are not clearly constricted in the median part.

\section{Key to SPecies of Hebeloma Section Hebeloma FROM ARCTIC-ALPINE HABITATS}

We provide below a key to the species of Hebeloma section Hebeloma that can be found in Arctic and alpine habitats in Europe. This includes all five species collected in the Carpathians plus H. nigellum, which has not yet been recorded in this region.

1. Spores amygdaloid with dextrinoidity D2 or D3 .....4

1. Spores amygdaloid or not, with dextrinoidity D0 or

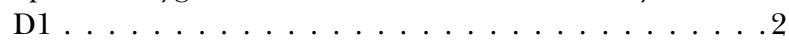

2. Ave. spore length at most $10 \mu \mathrm{m}$ or ave. spore width less than $6 \mu \mathrm{m}$ and spores elliptical, only rarely amygdaloid, associated with various trees and shrubs .... H. mesophaeum

2. Ave. spore length greater than $10 \mu \mathrm{m}$ and ave. spore width at least $6 \mu \mathrm{m}$ or if spores smaller then many spores amygdaloid, always with Saliceaceae. . . . . . . .

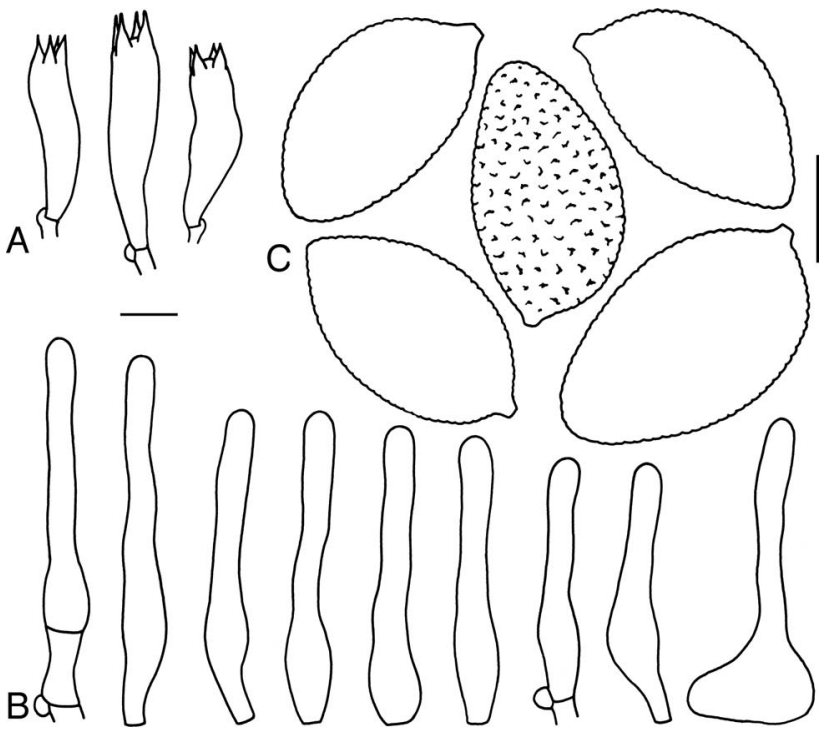

FIG. 8. Line drawing of Hebeloma oreophilum KRAM F57422 (HJB 14234) (holotype). A. Basidia $\times$ 1600. B. Cheilocystidia $\times 1000$; bar $=10 \mu \mathrm{m}$. C. Spores $\times 1600$; bar $5 \mu \mathrm{m}$.

3. Spores with some clear ornamentation $(\mathrm{O} 1, \mathrm{O} 2)$ and an indistinct but clear dextrinoid reaction (D1).....

....................... dunense

3. Spores showing almost no ornamentation, even under immersion (O1) or completely indextrinoid

(D0) ................... marginatulum

4. Number of complete lamellae (L) at least $40 \ldots \ldots \ldots$.

$\ldots \ldots \ldots \ldots \ldots \ldots \ldots \ldots$. oreophilum

4. Number of complete lamellae (L) less than $40 \ldots \ldots 5$

5. Ave. spore length at least $15 \mu \mathrm{m} . . . \ldots$. . grandisporum

5. Ave. spore length less than $15 \mu \mathrm{m} . . . \ldots \ldots$. . . nigellum

\section{DISCUSSION}

We begin this discussion by again stressing the difficulty that mycologists have had with regard to morphological species delimitation in the genus Hebeloma and hence the confusion over species determination. Vesterholt (2005) stressed that literature references of H. alpinum should be treated with caution; as an example he referred to misinterpretation of this species by Bruchet (1970).

Many Hebeloma species have been exclusively reported from alpine and Arctic habitats (e.g. Bruchet 1970, Vesterholt 2005, Eberhardt et al. 2015). It is also interesting that a high number of otherwise typically lowland species can be found in Arctic and alpine environments, so it is possible that the potential to grow in cold environments is characteristic of many of the Hebeloma species. In the Carpathians we found 11 species. Three of them belong to the Arctic-alpine geographical element. They are Hebeloma alpinum, 
H. marginatulum and H. oreophilum. The first two species are common in Arctic and alpine regions. They have been reported from numerous localities in Greenland, Iceland, Russian Arctic, Svalbard, Scandinavian mountains, the Alps and the Pyrenees (e.g. Favre 1955, Bruchet 1970, Gulden and Lange 1971, Ohenoja 1971, Kühner and Lamoure 1986, Senn-Irlet et al. 1990, Heinrich and Olech 1999, Karatygin et al. 1999, Borgen et al. 2006, Corriol 2008). Hebeloma alpinum also was reported from Alaska and the Rocky Mountains (Miller 1998, Cripps and Horak 2008).

In the Carpathians H. alpinum appears common, recorded at seven localities in three massifs (FIG. 3). Based on the material we have studied we can confirm the occurrence of this species in Greenland, Iceland, Svalbard, Scandinavia, the Alps and the Pyrenees. In addition, we have records from Canada. Hebeloma alpinum occurs with Salix spp. and Dryas spp. and it has been reported to form mycorrhizae with both (e.g. Debaud et al. 1981, Eberhardt et al. 2015). All Carpathian records of this fungus are from calcareous areas where it grew among Dryas octopetala (sometimes together with Salix reticulata), but of note in the Builă-Vănturariţa Mountains the species was growing with Helianthemum sp. (Fig. 4B). Although Dryas octopetala is also present in this area, it was not recorded in near the fungus, so it is likely that $H$. alpinum forms mycorrhizae also with Helianthemum sp. As far as we are aware this is the first time it has been recorded with this association.

Hebeloma marginatulum was recorded by us only once in the Tatra Mountains (the highest Carpathian massif) (FIg. 3) on siliceous bedrock and close to Salix herbacea, but Bruchet (1970) and Fellner and Landa (1993) report the species at three calcereous localities in this part of the Carpathians. Again we would suggest caution in that G. Bruchet, for instance, appears not to have been aware that the morphologically similar $H$. dunense also occurs in these habitats. We suspect his concept of $H$. marginatulum embraced both of these species. We found H. marginatulum on siliceous bedrock and close to Salix herbacea, but other Carpathian records are from siliceous and calcareous areas. According to Gulden and Lange (1971) H. marginatulum also probably was reported from the Caucasus Mountains and also has been reported from the Scottish Highlands (e.g. Watling 1987). However, we have examined this collection from Scotland both molecularly and morphologically and find it to be conspecific with $H$. mesophaeum. For $H$. marginatulum we have studied 65 collections. They are all from alpine or Arctic habitats, confirming species occurrence known from the literature in Greenland, Iceland, Svalbard, the Alps and the Norwegian mountains and also from subArctic area of Finland, Canadian Arctic and the
Rocky Mountains of USA. Salix is recorded as a potential host for all these collections.

The newly described $H$. oreophilum seems to prefer base rich or neutral soils. All our Carpathian records of this species are from calcareous bedrock, where it was growing among Salix reticulata, S. retusa or Dryas octopetala.

Hebeloma dunense, a species originally described from sand dunes associated with Salix repens (Corbière and Heim 1929) occurs in a range of habitats. One Arctic report of the fungus is from Greenland (Borgen et al. 2006, as $H$. collariatum). As explained above we think it has been confused with $H$. marginatulum. However, out of 185 collections of Hebeloma dunense we have studied, 77 are alpine or Arctic, from Canada, France, Greenland, Italy, Russian Federation, Svalbard, Sweden, Switzerland and USA. All Carpathian records of the species are from non-calcareous locations with Salix retusa or $S$. reticulata.

Another species that is frequent in Arctic-alpine habitats as well as in lowland habitats is H. mesophaeum. It has been reported from many Arctic and alpine localities including Greenland, Svalbard, Russian Arctic, Scandinavian mountains, the Alps, the Pyrenees, the Rocky Mountains and the Bargusin Mountains in Russia (e.g. Favre 1955, Gulden and Lange 1971, Nezdoiminogo 1971, Ohenoja 1971, Karatygin et al. 1999, Borgen et al. 2006, Corriol 2008, Cripps and Horak 2008). Out of 286 collections we have analyzed, 67 are from alpine or Arctic locations in Austria, Canada, Faroe Islands, France, Greenland, Iceland, Italy, Norway, Scotland, Svalbard, Sweden, Switzerland and USA. The species also belongs to the set of the most common Hebeloma sp. in the alpine zone of the Carpathians; it was reported from eight ecologically diverse (calcareous and siliceous) localities dispersed throughout the range (Fig. 3).

The remaining species are typical lowland fungi but can be encountered in high-mountain ecosystems. The recently described $H$. aanenii is known to occur in both alpine and Arctic habitats but is uncommon in such environments (Eberhardt et al. 2015). Out of 94 collections of this taxon we have studied, only three are from alpine/Arctic habitats, namely from France and Iceland with Salix and from Switzerland with Dryas. The present record of $H$. aanenii from the Carpathians originates from a slightly lowered alpine belt $(1720 \mathrm{~m})$ in the Nízke Tatry Mountains in vegetation including ectomycorrhizal hosts as Salix sp. and Bistorta vivipara.

Hebeloma vaccinum was reported from Greenland and the polar part of the Ural Mountains (Karatygin et al. 1999, Borgen et al. 2006). Out of 76 collections we have analyzed seven from alpine or Arctic locations, two each from Greenland and Iceland and one each from each of France, Sweden and Switzerland. All 

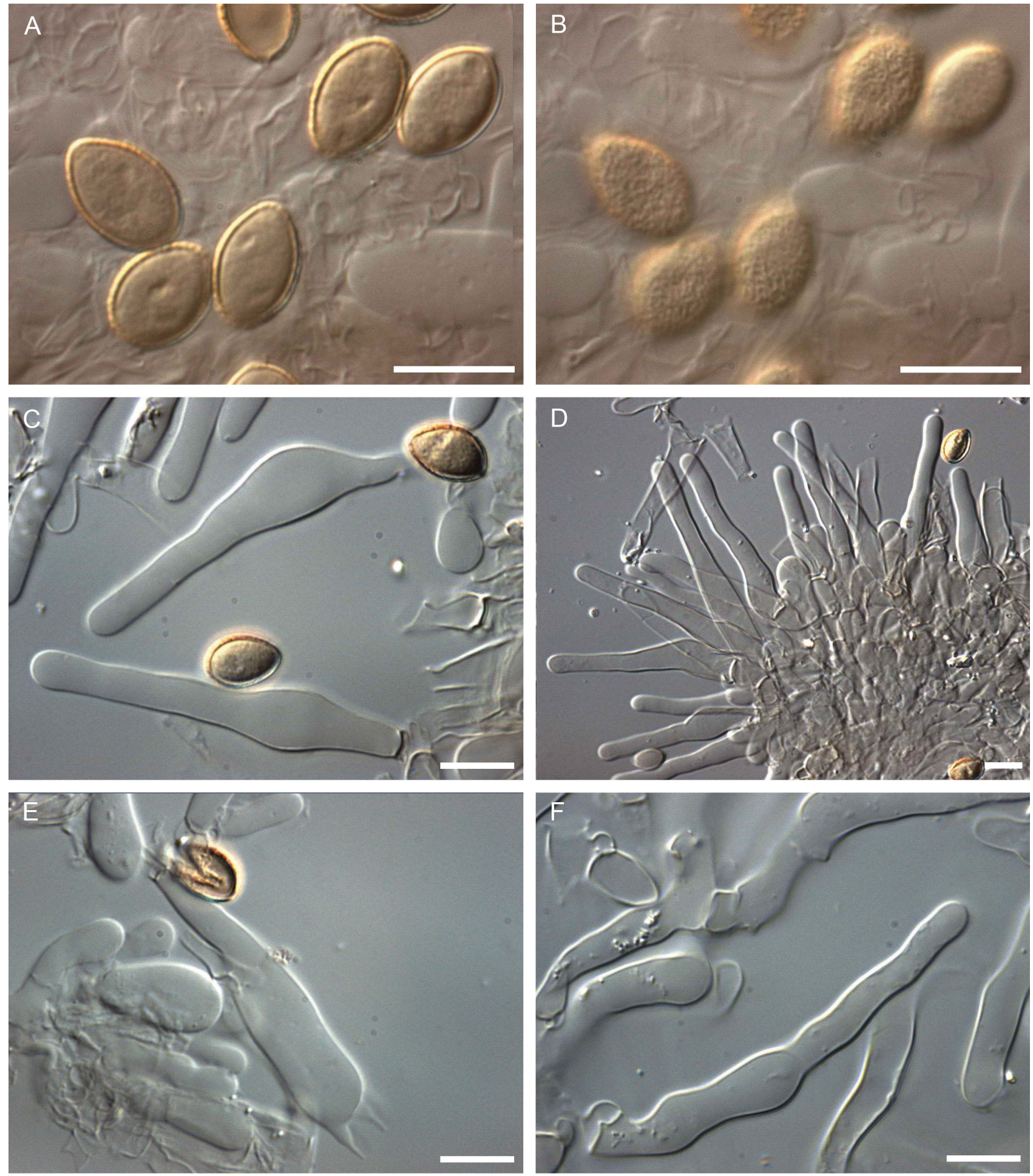

Fig. 9. Hebeloma oreophilum KRAM F-57422 (HJB14234) (holotype): A-B. Spores $\times 1600$ in $5 \%$ KOH. B. Spore ornamentation; C-D. Cheiloystidia $\times 1000$ and $\times 500$, respectively. E. Basidium $\times 1000$. F. Caulocystidia $\times 1000$. Bars $=$ $10 \mu \mathrm{m}$. Photographs by H.J. Beker.

records note the presence of Salix. The eighth, the Carpathian, alpine locality of the species is from a calcareous massif where Salix reticulata grows together with Dryas octopetala.
Within our 44 collections from the Carpathians there are four collections of $H$. laterinum. Three of these collections are not from true alpine habitats but from relic localities of Dryas octopetala at $790 \mathrm{~m}$. 
However, the fourth collection, recorded with Salix retusa, was collected at $1945 \mathrm{~m}$ on Mount Baranec in the Tatra Mountains and arguably could be regarded as being alpine. Hebeloma laterinum has been reported (as $H$. edurum) from the alpine belt of the Alps and the Pyrenees (Favre 1955, Bruchet 1970, Vila et al. 1998, Corriol 2008). Out of 87 collections of this taxon that we have studied in detail this is only the third from an alpine location; the others being the collections of Favre in 1946 at $2350 \mathrm{~m}$ with Dryas and according to Favre (1955) well above the tree line of the pines and that of Bruchet in 1966 (as H. edurum cited by Bruchet 1970) in Graubünden in the Swiss Alps at an altitude of $2400 \mathrm{~m}$ also with Dryas and with Pinus mugo present. Hebeloma laterinum is usually recorded with Fagaceae or Pinaceae in both low-altitude and subalpine habitats and also occasionally with Helianthemum. At our alpine locality we have not recorded the presence of Pinus mugo but the site is situated at $1950 \mathrm{~m}$, and thus the presence of scattered plants or seedlings of Pinus mugo in the vicinity of fungus cannot be excluded. The relic site of Dryas octopetala is located on a calcareous crest inside a pine forest (Pinus sylvestris), so pine is the most likely mycorrhizal symbiont of the fungus there.

Hebeloma naviculosporum is uncommon, and all of the other 12 collections we have studied list Picea or Pinus as the most likely mycorrhizal partner. As mentioned above the presence of Pinus mugo at the locality cannot be excluded and although the fungus was growing among Salix retusa it might have been associated with a dwarf pine there. However, we cannot exclude the possibility that Salix retusa among which the basidiomes were found is also a mycorrhizal partner of the fungus at that locality. The Carpathian record is the first alpine locality of $H$. naviculosporum.

Hebeloma velutipes is common and as we mentioned above it appears to be ecologically unspecific and has been recorded with a multitude of mycorrhizal associates. We are aware of one Arctic literature record of this fungus in Iceland (Heinrich and Olech 1999, as $H$. longicaudum ss. Lange). We have analyzed almost 350 records of this taxon and apart from these records from the Carpathians there were 15 other collections from Arctic or alpine localities, from Finland, Greenland, Spain, Svalbard and Switzerland with Dryas and Salix recorded roughly in equal proportions as associate. We have nine collections of this fungus from the Carpathians, and all of them pertain to the western part of the range.

Eleven species of Hebeloma including six typical Arctic-alpine ones seems like a small number given that there are 17 European Arctic-alpine specialists from the genus. However, the alpine belt of the Carpathians is relatively small in comparison to, for example, the
Alps (Ozenda 1985) or Arctic regions in the north and its fragmentation may be a reason for impoverishment of the fungal biota represented by Hebeloma species. In comparison we studied 146 collections from the Alps, across Austria, France, Italy and Switzerland; these represent 15 different species of which eight are typical Arctic-alpine specialists.

The taxonomy of fungi, also and especially to species has changed so much in recent years that observations from premolecular times or data from metagenomic ITS studies from bulk samples will not give a reliable picture of the Hebeloma species of a given region, particularly not of an alpine region (Eberhardt et al. 2015). East of the Carpathians is still terra incognita in view of modern treatments of Hebeloma; with this study we have made a start to shed light on the Hebeloma species diversity of the Carpathians.

\section{ACKNOWLEDGMENTS}

We are very much obliged to Grit Walther for providing microscopic drawings and to Tracey Prendergast for a set of maps on short notice, even if it was not used, to Marta Saługa for technical laboratory assistance. Furthermore, we are much indepted to S. Adamčík, J. Cieślak, V. Kautman, H. Knudsen, V. Kučera, P. Mleczko, W. Paul and M. Ronikier for company in the field and to D. Aanen, P. Ardron, L. Ballester, M.L. Beker, P. Cullington, M. Floriani, D. Ghyselinck, M. Ghyselinck, K. Kokkonen, M. Lenne, M. Meusers, A. Taylor, J. Vesterholt and any other collectors we might have forgotten by accident for supplying us with interesting and exciting Hebeloma collections from outside the Carpathians used to complete the sampling. This research was partly supported by the Polish National Science Centre (project N N303 308237) and by the statutory fund of the W. Szafer Institute of Botany of the Polish Academy of Sciences.

\section{LITERATURE CITED}

Aanen DK, Kuyper TW, Hoekstra RF. 2001. A widely distributed ITS polymorphism within a biological species of the ectomycorrhizal fungus Hebeloma velutipes. Mycol Res 105:284-290, doi:10.1017/S0953756201003628

Bálint M, Ujvárosi L, Theissinger K, Lehrian S, Mészáros N, Pauls SU. 2011. The Carpathians as a major diversity hotspot in Europe. In: Zachos FE, Habel JC, eds. Biodiversity hotspots. Berlin, Heidelberg: Springer Verlag. p 189-205, doi:10.1007/978-3-642-20992-5_11

Bjorbækmo MFM, Carlsen T, Brysting A, Vrålstad T, Hjøiland K, Ugland KI, Geml J, Schumacher T, Kauserud H. 2010. High diversity of root-associated fungi in both alpine and Arctic Dryas octopetala. BMC Pl Biol 10:244, doi:10.1186/1471-2229-10-244

Bon M. 1986. Chronique de mycologie alpine. Melanoleuca et Hebeloma. Bull trimestriel Féd Mycol Dauphiné-Savoie 102:21-24.

Borgen T, Elborne SA, Knudsen H. 2006. A checklist of the Greenland basidiomycetes. In: Boertmann D, Knudsen $\mathrm{H}$, eds. Arctic and alpine mycology 6. Proceedings of 
the 6th International Symposium on Arcto-Alpine Mycology (ISAM 6), Greenland, 11-21 Aug 2000. Meddelelser om Gronland, Bioscience 56:37-59.

Botnen S, Vik U, Carlsen T, Eidesen PB, Davey ML, Kauserud H. 2014. Low host specificity of root-associated fungi at an Arctic site. Mol Ecol 23:975-985, doi:10.1111/ mec. 12646

Bruchet G. 1970. Contribution a l'étude du genre Hebeloma (Fr.) Kummer. Bull Mens Soc Linn Lyon 39(suppl. 6):1-131.

Corbière L, Heim R. 1929. Champignons de la Manche. Mem Soc Sci Nat Cherbourg 40:166-167.

Corriol G. 2008. Checklist of Pyrenean alpine-stage macrofungi. In: Høiland K, Økland RH, eds. Arctic and alpine mycology VII. Sommerfeltia 31:29-99, doi:10.2478/ v10208-011-0004-6

Cripps CL, Horak E. 2008. Checklist and ecology of Agaricales, Russulales and Boletales in the alpine zone of the Rocky Mountains (Colorado, Montana, Wyoming) at 3000-4000 m a.s.l. In: Høiland K, Økland RH, eds. Arctic and alpine mycology VII. Sommerfeltia 31:101123, doi:10.2478/v10208-011-0005-5

Debaud JC, Pepin R, Bruchet G. 1981. Etude des ectomycorhizes de Dryas octopetala. Obtention de synthèses mycorhiziennes et de carpophores d'Hebeloma alpinum et H. marginatulum. Can J Bot 59:1014-1020, doi:10.1139/b81-138

Eberhardt U. 2012. Methods for DNA barcoding of fungi. Methods Mol Biol 858:183-205, doi:10.1007/978-161779-591-6_9

-, Beker HJ, Vesterholt J. 2015. Decrypting the Hebeloma crustuliniforme complex: European species of Hebeloma section Denudata subsection Denudata (Agaricales). Persoonia 35:101-147, doi:10.3767/ 003158515X687704

, Dukik K, Walther G, Vila J, Fernandez Brime S. 2013. European species of Hebeloma section Theobromina. Fungal Divers 58:103-126, doi:10.1007/ s13225-012-0188-3

Favre J. 1955. Les champignons supérieurs de la zone alpine du Parc National Suisse. Ergebn Wiss Untersuch Schweiz Nationalparkes 5:1-212

Fellner R, Landa J. 1993. Some species of Cortinariaceae and Russulaceae in the alpine belt of the Belaer Tatras II. Czech Mycol 47:45-57.

Fujiyoshi M, Yoshitake S, Watanabe K, Murota K, Tsuchiya Y, Uchida M, Nakatsubo T. 2011. Successional changes in ectomycorrhizal fungi associated with the polar willow Salix polaris in a deglaciated area in the High Arctic, Svalbard. Polar Biol 34:667-673, doi:10.1007/s00300-0100922-9

Gardes M, Dahlberg A. 1996. Mycorrhizal diversity in Arctic and alpine tundra: an open question. New Phytol 133:147-157, doi:10.1111/j.1469-8137.1996.tb04350.x

Geml J, Timling I, Robinson CH, Lennon N, Nusbaum HC, Brochmann C, Noordeloos ME, Taylor DL 2012. An Arctic community of symbiotic fungi assembled by longdistance dispersers: phylogenetic diversity of ectomycorrhizal basidiomycetes in Svalbard based on soil and sporocarp DNA. J Biogeogr 39:74-88, doi:10.1111/ j.1365-2699.2011.02588.x

Gulden G, Lange M. 1971. Studies in Macromycetes Flora of Jotunheimen, the central mountain massif of Norway. Norw J Bot 18:1-46.

Heilmann-Clausen J, Verbeken A, Vesterholt J. 1998. The genus Lactarius. Mundelstrup: Svampetryk. 287 p.

Heinrich Z, Olech MA. 1999. Interesting species of fungi (macromycetes) from Iceland (poster). In: RepelewskaPękalowa J, ed. Polish polar studies. XXVI polar symposium Lublin, Poland: Maria-Skłodowska University Press. p 343-344.

Heykoop M, Moreno G, Esteve-Raventós F. 1992. Hebeloma naviculosporum sp. nov. in peninsular Spain. Mycotaxon 45:495-502.

Kauff F, Lutzoni F. 2002. Phylogeny of the Gyalectales and Ostropales (Ascomycota, fungi): among and within order relationships based on nuclear ribosomal RNA small and large subunits. Mol Phylogene Evol 25:138156, doi:10.1016/S1055-7903(02)00214-2

Karatygin IV, Nezdominogo EL, Novozhilov YuK, Zhurbenko MP. 1999. Russian Arctic fungi. Checklist. St Petersburg: Russian Academy of Sciences, V.L. Komarov Botanical Institute. 212 p.

Kliment J, Valachovič M. 2007. Rastlinné spoločenstvá Slovenska. 4. Vysokohorská vegetácia. Bratislava: Veda. $386 \mathrm{p}$.

Körner C. 2003. Alpine Plant Life. Berlin-Heidelberg: Springer-Verlag. 344 p, doi:10.1007/978-3-642-18970-8

Kondracki J. 1978. Karpaty. Warszawa: Wydawnictwa Szkolne i Pedagogiczne. 273 p.

Kühner R, Lamoure D. 1986. Catalogue des Agaricales (Basidiomycètes) de la zone alpine du Parc National de la Vanoise et des régions limitrophes. Tr scient parc nat vanoise 15:103-187.

Largent DL, Baroni TJ. 1988. How to identify mushrooms to genus VI: modern genera. Eureka, California: Mad River Press. 277 p.

Lentendu G, Zinger L, Manel S, Coissac E, Choler P, Geremia RA, Melodelima C. 2011. Assessment of soil fungal diversity in different alpine tundra habitats by means of pyrosequencing. Fungal Divers 49:113-123, doi:10.1007/s13225-011-0101-5

Marmeisse R, Gryta H, Fraisinet-Tachet L, Gay G, Debaud JC. 1999. Hebeloma. In: Cairney JWG, Chambers SM, eds. Ectomycorrhizal Fungi-key genera in profile. Berlin: Springer. p 89-127, doi:10.1007/978-3-662-06827-4_4

Miller MA, Pfeiffer W, Schwartz T. 2010. Creating the CIPRES science gateway for inference of large phylogenetic trees. In: Proceedings of the Gateway Computing Environments Workshop (GCE), New Orleans, 2010. p 1-8.

Miller OK Jr. 1998. Hebeloma in the Arctic and alpine tundra in Alaska. In: Mukhin VA, Knudsen H, eds. Arctic and alpine mycology 5. Proceedings of the 5th International Symposium on Arcto-Alpine Mycology (Labytnangi, Russia, 15-27 Aug 1996). p 86-97.

Nespiak A. 1960. Notatki mikologiczne z Tatr. Fragm Florist Geobot 6:709-724. 
Nezdoyminoho EL. 1971. Mushrooms of high-mountain belts in Bargusin mountain range. Mikol Fitopatol 5:85-87.

Ohenoja E. 1971. The larger fungi of Svalbard and their ecology. Rep Kevo SubArctic Res Stat 8:122-147.

Ozenda P. 1985. La végétation de la chaîne Alpine dans l'éspace montagnard européen. Paris: Masson. 330 p.

Pawłowski B. 1970. Remarques sur l'endemisme dans la flore des Alpes et des Carpates. Vegetatio 21:181-235, doi:10. 1007/BF02269663

Pilát A. 1926. Les Agaricales et Aphyllophorales des Carpathes centrales. Bull Soc Mycol Fr 62:81-120.

Rambaut A. 2012. FigTree. Tree figure drawing tool 1.4.0. Institute of Evolutionary Biology, University of Edinburgh. http:/ / tree.bio.ed.ac.uk/

Ronikier A. 2008. Contribution to the biogeography of Arctic-alpine fungi: first records in the southern Carpathians (Romania). In: Høiland K, Økland RH, eds. Arctic and alpine mycology VII. Sommerfeltia 31:191211, doi:10.2478/v10208-011-0011-7

- 2011. Biogeography of high-mountain plants in the Carpathians: an emerging phylogeographical perspective. Taxon 60:373-389.

—, Ronikier A. 2011. Rhizomarasmius epidryas (Physalacriaceae): the phylogenetic placement of an Arcticalpine fungus with obligate saprobic affinity to Dryas spp. Mycologia 103:1124-1132, doi:10.3852/11-018

, Schneeweiss GM, Schönswetter P. 2012. The extreme disjunction between Beringia and Europe in Ranunculus glacialis s. 1. (Ranunculaceae) does not coincide with the deepest genetic split-a story of the importance of temperate mountain ranges in Arctic-alpine phylogeography. Mol Ecol 21:5561-5578, doi:10.1111/mec.12030
Senn-Irlet B, Jenssen KM, Gulden G. 1990. Arctic and Alpine Fungi 3. Oslo: Soppkonsulenten A/S. 58 p.

Stamatakis A. 2014. RAxML 8: a tool for phylogenetic analysis and post-analysis of large phylogenies. Bioinformatics 30:1312-1313, doi:10.1093/bioinformatics/btu033

Stielow B, Eberhardt U, Robert V, Verkley G, Stalpers J, Lesage-Meessen L. 2014. Set of new genes to use in addition or replacement of ribosomal sequences 0.1. European Consortium of Microbial Resource Centres JRA 2 D 15.19 Report. http://www.embarc.eu/deliverables/ EMbaRC_D.JRA2.1.1_D15.19_new-genes-fungi.pdf

Timling I, Taylor DL. 2012. Peeking through a frosty window: molecular insights into the ecology of Arctic soil fungi. Fungal Ecol 5:419-429, doi:10.1016/j.funeco.2012.01.009

Vaidya G, Lohman DJ, Meier R. 2011. SequenceMatrix: concatenation software for the fast assembly of multigene datasets with character set and codon information. Cladistics 27:171-180, doi:10.1111/j.1096-0031.2010.00329.x

Vesterholt J. 1989. A revision of Hebeloma sect. Indusiata in the Nordic countries. Nord J Bot 9:289-319, doi:10.1111/ j.1756-1051.1989.tb01004.x

. 2005. The genus Hebeloma. Fungi of northern Europe. Vol. 3. Tilsit: Svampetryk. 146 p.

_ , Eberhardt U, Beker HJ. 2014. Epitypification of Hebeloma crustuliniforme. Mycol Prog 13:553-562, doi:10. 1007/s11557-013-0938-y

Vila J, Llistosella J, Llimona X. 1998. Contributió al coneixement dels fongs de l'estatge alpí dels Pirineus de Catalunya II. Rev Catalana Micol 21:93-113.

Watling R. 1987. Larger Arctic-alpine fungi in Scotland. In: Laursen GA, Ammirati JF, Redhead SA, eds. Arctic and alpine mycology II. Environ Sci Res 34:17-45, doi:10.1007/978-1-4757-1939-0_3 